\title{
EVAPOTRANSPIRAÇÃO E COEFICIENTE DE CULTURA EM DOIS CICLOS DE PRODUÇÃO DO MARACUJAZEIRO
}

AMARELO

\section{RODRIGO ALESSANDRO DE LIMA CORRÊA}

\begin{abstract}
Dissertação apresentada à Escola Superior de Agricultura “Luiz de Queiroz”, Universidade de São Paulo, para obtenção do título de Mestre em Agronomia, área de concentração: Irrigação e Drenagem.
\end{abstract}

PIRACICABA

Estado de São Paulo - Brasil

Maio - 2004 


\section{EVAPOTRANSPIRAÇÃO E COEFICIENTE DE CULTURA EM DOIS CICLOS DE PRODUÇÃO DO MARACUJAZEIRO AMARELO}

\section{RODRIGO ALESSANDRO DE LIMA CORRÊA}

Engenheiro Agrônomo

Orientador: Prof. Dr. JOSÉ ANTONIO FRIZZONE

Dissertação apresentada à Escola Superior de Agricultura "Luiz de Queiroz", Universidade de São Paulo, para obtenção do título de Mestre em Agronomia, área de concentração: Irrigação e Drenagem.

PIR A CIC A B A

Estado de São Paulo - Brasil

Maio - 2004 
Dados Internacionais de Catalogação na Publicação (CIP)
DIVISÃO DE BIBLIOTECA E DOCUMENTAÇÃO - ESALQ/USP

Corrêa, Rodrigo Alessandro de Lima

Evapotranspiração e coeficiente de cultura em dois ciclos de produção do

maracujazeiro amarelo / Rodrigo Alessandro de Lima Corrêa. - - Piracicaba, 2004.

57 p. : il.

Dissertação (mestrado) - - Escola Superior de Agricultura Luiz de Queiroz, 2004.

Bibliografia.

1. Coeficiente de cultura 2. Desenvolvimento vegetal 3. Evapotranspiração 4. Fenolog 5. Irrigação 6. Maracujá 7. Modelo de Penman-Monteith I. Título

CDD 634.425

"Permitida a cópia total ou parcial deste documento, desde que citada a fonte - O autor" 
A Deus, pela vida, saúde e paz.

AGRADEÇO

A meus pais Waldir Corrêa e Izaura Garcia de Lima Corrêa, que sempre me apoiaram e proporcionaram a formação superior; A meu irmão Emanuel Roberto de Lima Corrêa, futuro Engenheiro Agrônomo.

DEDICO

A todos que acreditaram em mim OFEREÇO 


\section{AGRADECIMENTOS}

Ao Departamento de Engenharia Rural da Escola Superior de Agricultura "Luiz de Queiroz" - Universidade de São Paulo, pela oportunidade concedida para a realização do curso;

À Coordenadoria do Aperfeiçoamento de Pessoal de Nível Superior - CAPES, pela concessão da bolsa de estudos;

Ao Prof. Dr. José Antônio Frizzone pelos ensinamentos, orientação e amizade durante o Curso de Graduação e Pós-Graduação;

Aos Professores Dr. Marcos Vinícius Folegatti e Dr. Rubens Duarte Coelho pelas valiosas sugestões e apoio na realização do experimento;

Ao Pesquisador da Embrapa Meio-Norte, Dr. Valdemício Ferreira de Sousa pelos ensinamentos, amizade, colaboração na realização do experimento e grande incentivador de minha vida científica;

Ao Prof. Dr. Nilson Augusto Villa Nova, pelos ensinamentos e valiosas sugestões na condução do experimento e análises dos dados;

Ao Amigo Eng. Agr. MSc. Ariovaldo Antonio Tadeu Lucas pela colaboração durante a condução do experimento e coleta dos dados experimentais;

Aos Professores do Curso de Pós-Graduação em Irrigação e Drenagem pelos ensinamentos;

Aos Colegas do Curso de Pós-Graduação em Irrigação e Drenagem: Boanerges Siqueira d'Albuquerque Júnior, Cláudio Ricardo da Silva, Guilherme Busi de Carvalho, José Alves Júnior, Leandro Fellet Lourenço, Luis Gonzaga Medeiros de Figueredo Júnior, Márcio Aurélio Lins dos Santos, Marco Antonio Jacomazzi, Nildo da Silva Dias, Ruben Alcides Franco Ibars, Tales Miler Soares, Tonny José Araújo da Silva, Vinícius 
Maia Costa e Wulf Schimidt pelas valiosas sugestões e colaboração na realização do trabalho;

Aos demais Colegas do Curso de Pós-Graduação em Irrigação e Drenagem, pela amizade e apoio durante o curso;

Aos Funcionários do Departamento de Engenharia Rural, pelo apoio durante a realização do curso e na execução do experimento;

Aos Estudantes do Curso de Graduação em Engenharia Agronômica da ESALQ/USP, Estagiários do Grupo de Práticas em Irrigação e Drenagem, pela amizade e colaboração na instalação e na condução do experimento;

A Todos aqueles que de alguma forma contribuíram para a realização desse trabalho. 


\section{SUMÁRIO}

Página

LISTA DE FIGURAS ................................................................................ viii

LISTA DE TABELAS …............................................................................ ix

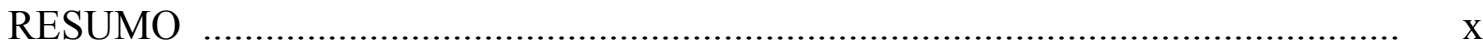

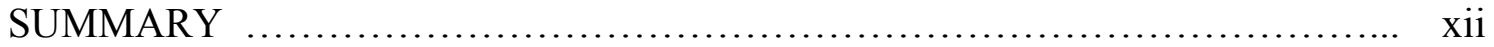

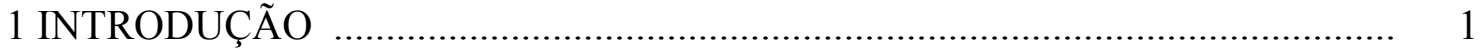

2 REVISÃO DE LITERATURA ................................................................... 3

2.1 A Cultura do maracujazeiro amarelo ............................................................... 3

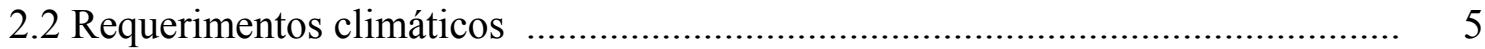

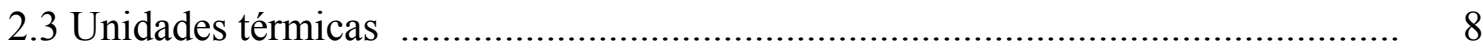

2.4 Déficit hídrico e Irrigação .............................................................................. 9

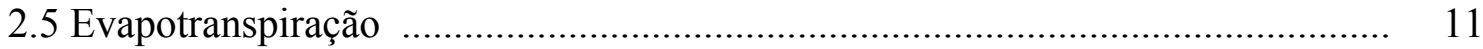

2.6 Evapotranspiração da cultura .................................................................. 14

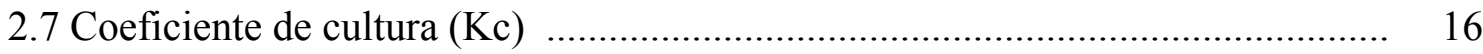

3 MATERIAL E MÉTODOS …................................................................. 18

3.1 Caracterização da área experimental ............................................................ 18

3.2 Manejo da Cultura .................................................................................. 22

3.3 Irrigação

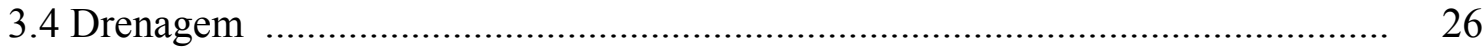

3.5 Umidade e variação de armazenamento de água no solo .................................. 26

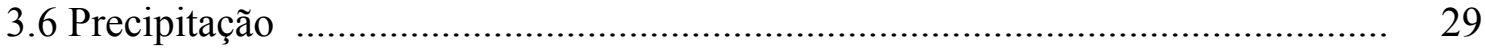

3.7 Determinação da Evapotranspiração da Cultura .............................................. 29

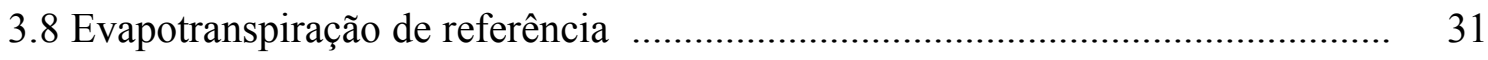




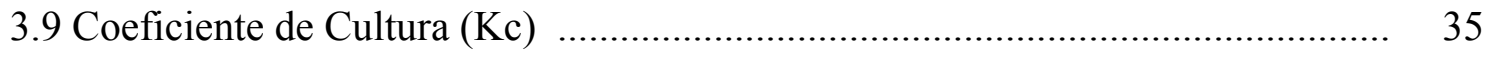

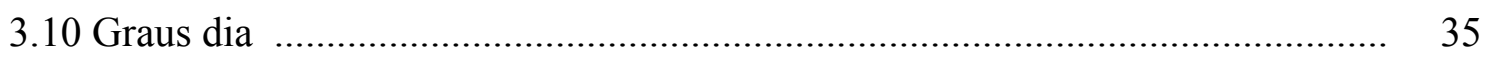

4 RESULTADOS E DISCUSSÃO …............................................................ 37

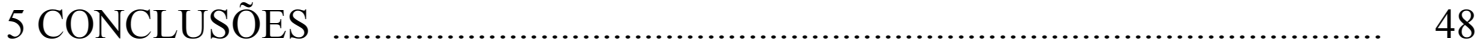

REFERÊNCIAS BIBLIOGRÁFICAS _....................................................... 49 


\section{LISTA DE FIGURAS}

Página

1 Vista aérea da área experimental e localização dos lisímetro de drenagem. ........ 19

2 Desenho esquemático do lisímetro com o sistema de drenagem......................... 20

3 Curvas de retenção de água no solo nos 4 lisímetros, em três profundidades. ..... 21

4 Detalhe das linhas de plantio e do lisímetro isento de ervas daninhas.................. 24

5 Detalhe dos lisímetros com o sistema de irrigação, o sistema de drenagem e os tensiômetros. ...........................................................................................

6 Desenho esquemático das áreas de influência dos tensiômetros nos lisímetros... 27

7 Partição da evapotranspiração do maracujazeiro e das plantas daninhas (a); evapotranspiração da cultura e evapotranspiração de referência ao longo dos estádios fenológicos da cultura do maracujazeiro (b).

8 Temperaturas máxima e mínima nos dois ciclos produtivos do maracujazeiro amarelo (a); Graus dia acumulado em todo o período de produção (b)................ 44

9 Valores de Kc ao longo de dois ciclos de produção do maracujazeiro amarelo... 47 


\section{LISTA DE TABELAS}

Página

1 Valores de densidade global do solo $\left(\mathrm{g} \mathrm{cm}^{-3}\right)$ dentro dos lisímetros .................. 20

2 Análise granulométrica das amostras de solo dentro dos lisímetros .................. 20

3 Parâmetros de ajuste da curva de retenção de van Genuchten (1980) ................ 22

4 Subperíodos com os respectivos intervalos de dias, considerados no cálculo da evapotranspiração da cultura ...................................................................... 30

5 Elementos climáticos médios para os subperíodos considerados ...................... 34

6 Valores médios dos componentes do balanço hídrico nos lisímetros: Irrigação (I), Precipitação (P), Drenagem (D), Variação do armazenamento $(\Delta \mathrm{S})$ e Evapotranspiração da cultura $(\mathrm{ETc})$.............................................................. 38

7 Valores de evapotranspiração da cultura somada à evapotranspiração das plantas daninhas (ETcm), evapotranspiração de referência (ETo) e coeficiente

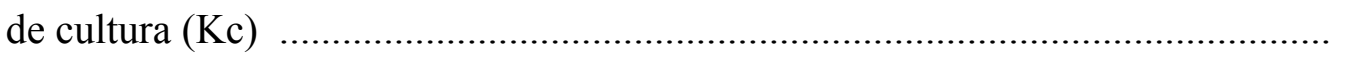

8 Características fenológicas nos estádios de desenvolvimento do maracujazeiro amarelo 


\title{
EVAPOTRANSPIRAÇÃO E COEFICIENTE DE CULTURA EM DOIS CICLOS DE PRODUÇÃO DO MARACUJAZEIRO AMARELO
}

\author{
Autor: RODRIGO ALESSANDRO DE LIMA CORRÊA \\ Orientador: Prof. Dr. JOSÉ ANTONIO FRIZZONE
}

\section{RESUMO}

Este trabalho teve como objetivo determinar a evapotranspiração da cultura (ETc) e o coeficiente de cultivo (Kc) do maracujazeiro amarelo (Passiflora edulis Sims f. flavicarpa Deg), durante 637 dias após o transplantio (DAT) das mudas. O experimento foi desenvolvido na área experimental da Fazenda Areão pertencente à ESALQ/USP, em Piracicaba, SP. A determinação da ETc foi realizada em 4 lisímetros de drenagem, instalados no centro de uma área de 0,4 ha cultivada com maracujazeiro amarelo, no espaçamento de 3,5 m x 4,0 m, desde 21/05/99 (17 DAT). A determinação do Kc foi realizada a partir da evapotranspiração de referência (ETo) estimada pelo método de Penmam-Monteith, considerando a evapotranspiração das plantas daninhas no somatório da evapotranspiração da cultura (ETcm). No período entre 32 e 91 DAT foram verificados baixos valores de ETc, devido a ocorrência de baixas temperaturas e radiação solar. A partir dos 91 DAT os valores foram crescentes atingindo o valor máximo de 23,37 L planta $^{-1} \mathrm{~d}^{-1}$ no período compreendido entre 287 e 308 DAT, máximo florescimento e frutificação. Considerando a área total do espaçamento, com 
ervas daninhas ocupando as entrelinhas, este valor foi de aproximadamente $2,68 \mathrm{~mm}$ $\mathrm{d}^{-1}$. Verificou-se que em condições de irrigação na área total, a evapotranspiração das plantas daninhas das entrelinhas deve ser considerada, pois podem corresponder a até $90 \%$ da evapotranspiração total da área. O consumo hídrico total no primeiro ciclo de produção foi de $650 \mathrm{~mm}$ em 447 dias, com acúmulo térmico de 5880 graus-dia. Os valores médios de Kc aumentaram de 0,24 a 0,89 seguindo o aumento da área foliar, observada em função da projeção da copa que variou de 0,06 a $4 \mathrm{~m}^{2}$. Durante o ciclo do maracujazeiro foram determinados 6 estádios de desenvolvimento, com valores de Kc de 0,3 para a fase de desenvolvimento inicial, 0,4 para a fase de crescimento vegetativo apical, 0,5 para a fase de crescimento vegetativo lateral, 0,9 para a fase de florescimento, frutificação e maturação dos frutos, 0,8 para a fase de repouso vegetativo e 0,7 para o início do florescimento e frutificação do segundo ciclo de produção. 


\title{
EVAPOTRANSPIRATION AND CROP COEFFICIENT IN TWO CYCLES OF PRODUCTION OF YELLOW PASSION FRUIT
}

\author{
Author: RODRIGO ALESSANDRO DE LIMA CORREAA \\ Adviser: Prof. Dr. JOSÉ ANTONIO FRIZZONE
}

\section{SUMMARY}

This work had as objective to determine the crop evapotranspiration (ETc) and the crop coefficient $(\mathrm{Kc})$ of yellow passion fruit (Passiflora edulis Sims f. flavicarpa Deg), during 637 days after the transplant (DAT) of the seedling. The experiment was carried out in the experimental field of Fazenda Areão which belongs to ESALQ/USP, in Piracicaba, São Paulo State, Brazil. The determination of the ETc was made in 4 drainage lysimeters, installed in the center of an area of 0.4 ha cultivated with yellow passion fruit, in the space distance of $3.5 \mathrm{~m} \mathrm{x} 4.0 \mathrm{~m}$, since 05/21/99 (17 DAT). The determination of $\mathrm{Kc}$ was accomplished by the evapotranspiration reference (ETo) estimated by Penmam-Monteith Method, considering the weed evapotranspiration in the amount of the crop evapotranspiration (ETcm). In the period between 32 and 91 DAT low values were verified of ETc, due to the low temperature and solar radiation. Through of 91 DAT the values increased and reached the maximum value of $23.37 \mathrm{~L} \mathrm{~d}^{-1}$ $\mathrm{p}^{-1}$ in the period comprised between 287 and 308 DAT, maximum flowering and fruit set. Considering the total area of the spacing, with weeds occupying the interlineations, this value was of approximately $2.68 \mathrm{~mm} \mathrm{~d}^{-1}$. It was verified that under irrigation 
conditions in the total area the evapotranspiration of the weeds of the interlineations should be considered, therefore they can correspond up to $90 \%$ of the total evapotranspiration of the area. The total crop evapotranspiration in the first production cycle was of $650 \mathrm{~mm}$ in 447 days, with thermal accumulation of 5880 degree day. The average values of $\mathrm{Kc}$ increased from 0.24 to 0.89 following the increase of the leaf area, it was observed in function of the projection of the cup that varied from 0.06 to $4 \mathrm{~m}^{2}$. The cycle of the passion fruit showed 6 development phases, with values of Kc 0.3 for the initial development phase, 0.4 for the growth vegetative phase, 0.5 for the lateral vegetative growth phase, 0.9 for the flowering phase, fruit set and maturation of the fruits, 0.8 for the vegetative rest phase and 0.7 for the beginning of the flowering and fruit set of the second production cycle. 


\section{INTRODUÇÃO}

O Brasil, nos últimos anos, tem sido o principal produtor de maracujá, com uma área aproximada de 33 mil ha que gera em torno de 220 mil empregos diretos e indiretos (Ruggiero, 2000). O Estado de São Paulo se destaca em segundo lugar de área plantada, com pomares formados por pequenos produtores, que são atraídos pelo rápido retorno financeiro e receitas distribuídas durante o ano (Souza \& Meletti, 1997). Isso demonstra que a cultura do maracujazeiro, assim como, a maior parte das culturas frutíferas, pode ser uma boa alternativa para os pequenos proprietários rurais, contribuindo para valorizar o trabalho da agricultura familiar e proporcionar a melhoria do nível sócioeconômico dessa parcela da população.

Com relação ao mercado consumidor, o maracujá é comercializado, principalmente, em forma de sulco e polpa. As exportações brasileiras são prejudicadas pelas elevadas tarifas de importação e também pelas barreiras fitossanitárias, sendo necessário um programa de comercialização, além da padronização das frutas quanto ao aspecto, sabor, coloração, formato e uniformidade de tamanho (Pizzol et al., 2000). Além disso, observa-se que o rendimento médio da cultura no Estado (16,8 $\left.\mathrm{t} \mathrm{ha}{ }^{-1}\right)$, mesmo estando 60\% acima da média nacional (FNP CONSULTORIA \& COMÉRCIO, 2003), ainda é muito baixo quando consideramos o potencial produtivo da cultura (30-45 $\left.\mathrm{t} \mathrm{ha}^{-1}\right)$.

A baixa produtividade dos pomares é citada por Ruggiero (2000) como um dos principais problemas que acometem a cultura, destacando a necessidade de pesquisas para melhor definir tecnologias de produção, dentre elas a irrigação, capazes de proporcionar o aumento da produtividade, a possibilidade do aumento na sobrevida da cultura e a melhoria da qualidade dos frutos, que são essenciais para o sucesso do 
agricultor. Segundo Martins (1998), a água e a adubação são os fatores que limitam o rendimento com maior intensidade, considerando um bom material genético e um bom controle de pragas e doenças. Deste modo, a aplicação racional da irrigação e da adubação são fundamentais para o aumento da produtividade e do retorno econômico do empreendimento.

A irrigação tem sido reconhecida como parte fundamental do manejo da cultura do maracujazeiro, não só como condição essencial, principalmente em regiões subúmidas e semi-áridas, mas também como alternativa de produção na entressafra, como é o caso da região sudeste. $\mathrm{O}$ uso da irrigação na cultura do maracujazeiro é relatado por Ruggiero et al. (1996) como indispensável, pois promove o aumento da produtividade e permite a obtenção de produção contínua e uniforme, com frutos de boa qualidade. É sabido que o estresse hídrico na cultura do maracujazeiro amarelo reduz o desenvolvimento vegetativo refletindo, conseqüentemente, no número de botões florais, além da queda de flores e frutos (Menzel et al., 1986; Ruggiero et al., 1996). Todavia, são poucas as informações na literatura sobre as necessidades hídricas dessa cultura, de forma a possibilitar um programa racional das irrigações. Portanto, a quantificação da necessidade hídrica da cultura, em seus estádios de desenvolvimento é de extrema necessidade, pois além de evitar danos por deficiência ou excesso hídrico na cultura, permite a racionalização dos recursos hídricos e a economia nos gastos energéticos.

Este trabalho teve como objetivo estimar a evapotranspiração, nos diferentes estádios fenológicos da cultura do maracujazeiro amarelo (Passiflora edulis Sims f. flavicarpa Deg), determinada em lisímetros de drenagem, e o coeficiente de cultura em função da evapotranspiração de referência estimada pelo método de Penman-Monteith. Além disso, determinou-se a necessidade térmica em cada período de desenvolvimento. 


\section{REVISÃO DE LITERATURA}

\subsection{A Cultura do maracujazeiro amarelo}

Originário da região tropical da América do Sul, a primeira referência botânica à família do maracujazeiro (Passifloraceae) ocorreu em 1569, quando Nic Monardis descreveu uma espécie do gênero Passiflora, a "Passiflora incarnata L", denominada genericamente de granadilla (Hoehne, 1946). Posteriormente, diversas descrições botânicas foram realizadas, caracterizando o gênero Passiflora com, aproximadamente, 530 espécies tropicais e subtropicais, das quais, 150 são originárias do Brasil (Medina et al., 1980). Dessas, apenas 60 espécies produzem frutos comercialmente aproveitáveis, destacando as espécies: Passiflora edulis Sins f. flavicarpa Deg (maracujá-amarelo), Passiflora edulis (maracujá-roxo) e Passiflora alata (maracujá-doce) (Vasconcellos \& Duarte Filho, 2000).

O maracujazeiro-roxo (Passiflora edulis) é a espécie plantada em 95\% dos pomares comerciais dos países produtores de maracujá, sendo cultivado, principalmente, na Austrália, Sri Lanka, Índia, Nova Zelândia e África do Sul (Silva, 2001). No Brasil, o maracujazeiro-amarelo (Passiflora edulis Sins f. flavicarpa Deg) é a espécie cultivada em maior escala, sendo amplamente comercializado de norte a sul do país (Souza \& Meletti, 1997).

O maracujazeiro amarelo é caracterizado botanicamente como uma planta trepadeira, perene, lenhosa, de crescimento rápido e contínuo, podendo atingir de $5 \mathrm{~m} \mathrm{a}$ $10 \mathrm{~m}$ de comprimento. O sistema radicular é do tipo pivotante ou axial, pouco profundo, com maior taxa de crescimento ocorrendo entre 210 e 300 dias e maior volume de raízes 
concentrado entre $0,30 \mathrm{~m}$ e $0,45 \mathrm{~m}$ de profundidade, em um raio de $0,60 \mathrm{~m}$ a partir do tronco (Medina et al., 1980; Manica, 1981; Kliemann et al., 1986; Sousa, 2000).

O caule, de secção circular, é lenhoso e bastante lignificado, diminuindo o teor de lignina à medida que se aproxima do ápice da planta. A partir do caule surgem as gemas vegetativas, cada uma dando origem a uma folha e uma gavinha. As folhas são simples e alternadas, possuindo na fase juvenil das plantas a forma ovalada e na fase adulta a forma lobada ou digitada. As flores, hermafroditas, são formadas nas axilas das folhas nascendo nos ramos do ano; possuem geralmente cinco estames presos a um androginóforo colunar bem desenvolvido e três estigmas que variam conforme a curvatura, determinando tipos de flores diferentes, com reflexos diferenciados na polinização. As flores geralmente abrem-se entre 12 e 13 horas, permanecendo abertas em torno de quatro horas (Ruggiero et al., 1996).

O maracujazeiro amarelo é dependente de polinização cruzada, pois suas flores apresentam diferentes graus de auto-incompatibilidade. A polinização é realizada por abelhas mamangavas (Xilocopa spp) ou através da polinização artificial, quando a presença dos insetos polinizadores é reduzida. Os frutos são do tipo baga, com tamanho e forma variados, de acordo com os diferentes estádios de maturação, idade da cultura, latitude, condições edafoclimáticas e sistema de manejo (Medina et al., 1980; Figueiredo et al., 1988).

A caracterização botânica da cultura do maracujazeiro foi realizada por Maciel et al. (1994) que dividiu o ciclo da cultura em quatro estádios de desenvolvimento. Inicialmente a cultura apresenta uma fase embrionária, onde a planta apresenta um hipocótilo ereto, duas folhas cotiledonares e um epicótilo pouco visível. Posteriormente a planta inicia a fase juvenil ou fase de crescimento inicial, onde a planta apresenta um caule cilíndrico com entrenós curtos, folhas simples dispostas em filotaxia $2 / 5$ e a presença de uma gema axilar. Esta fase termina com o aparecimento das primeiras folhas lobadas e gavinhas, o que ocorre no final do segundo giro filotáxico. A próxima fase, caracterizada como de crescimento vegetativo apical é uma fase de transição, em que ocorrem mudanças fisiológicas e morfológicas com o aumento do comprimento dos entrenós, mudança na forma das folhas, aparecimento de gavinhas e crescimento do 
ramo principal. O crescimento vegetativo lateral, também caracterizado como fase de transição, corresponde ao desenvolvimento de dois ramos laterais, de onde saem os ramos produtivos. Nesta fase, a partir do $11^{\circ}$ nó, entre a base e a gema axilar, dá-se início ao aparecimento de gavinhas em todos os nós, ocorrendo também o surgimento das primeiras folhas trilobadas. Com o aparecimento de botões florais e flores nos ramos principal e lateral, inicia-se a fase adulta da cultura que ocorre até a paralisação do florescimento e frutificação em função da redução da temperatura e do fotoperíodo.

\subsection{Requerimentos climáticos}

A cultura do maracujazeiro, apesar de ser considerada uma espécie tropical, desenvolve-se em diversas condições climáticas, variando desde as regiões quentes dos trópicos até locais com clima subtropical ( $35^{\circ}$ latitude sul). Ainda nas diferentes latitudes, é cultivado em altitudes que variam desde o nível do mar até $3.200 \mathrm{~m}$ de altura (Menzel \& Simpson, 1988). Nessas regiões, as plantas apresentam crescimento e desenvolvimento em taxas bem distintas, ocasionando grandes variações no ciclo de produção da cultura, de acordo com o fotoperíodo, a temperatura, a radiação solar e a precipitação pluviométrica (Menzel \& Simpson, 1988).

Nas localidades com latitudes mais altas, os ciclos de produção decrescem proporcionalmente ao número de meses com fotoperíodos inferiores a 11 horas, e ao decréscimo da radiação solar global incidente. O estresse hídrico, associado a dias curtos e às baixas temperaturas do ar, restringe o crescimento e o potencial produtivo da cultura (Menzel et al., 1986).

De modo geral, o maracujazeiro amarelo é mais adaptado às regiões de clima quente, com temperaturas médias mensais entre $21^{\circ} \mathrm{C}$ e $32^{\circ} \mathrm{C}$, precipitação pluviométrica anual entre $800 \mathrm{~mm}$ e $1750 \mathrm{~mm}$, baixa umidade relativa, fotoperíodo em torno de 11 horas e ventos moderados (Medina et al., 1980; Ruggiero et al., 1996).

O primeiro estudo sobre a influência do fotoperíodo no desenvolvimento do maracujazeiro amarelo, foi realizado por Watson \& Bowers (1965) que verificaram a 
maior produtividade da cultura em fotoperíodo acima de 12 horas de luz, e redução do número de flores com o abaixamento do fotoperíodo. Ainda segundo esses autores, o efeito do fotoperíodo sobre o crescimento vegetativo foi marcante, onde em fotoperíodos menores que 8 horas e maiores que 16 horas, as plantas apresentaram um aumento acentuado no crescimento (comprimento do ramo, comprimento do entrenó, e número de nós) em detrimento ao florescimento, ao passo que plantas expostas a fotoperíodos de 12 horas apresentaram menor crescimento, porém maior número de flores.

Vasconcellos \& Duarte Filho (2000) descreveram a influência do fotoperíodo nos cultivos realizados nas diferentes regiões geográficas do Brasil, em condições de não limitação hídrica. No Norte do país $\left(0^{\circ}\right.$ latitude) as plantas crescem e florescem continuadamente, devido a pouca variação da temperatura e fotoperíodo ao longo do ano. Afastando-se para o Nordeste, este período começa a diminuir (10 a 11 meses) em função da latitude, uma vez que temos o aparecimento de um inverno mais delimitado com uma pequena redução na temperatura e no fotoperíodo. No Sudeste, o período de produção é menor em relação ao Nordeste, variando de 10 a 9-8 meses, uma vez que nesta região no outono/inverno as temperaturas são mais baixas e o comprimento do dia diminui mais acentuadamente. Na região Sul, os efeitos da temperatura e fotoperíodo são fortes, reduzindo ainda mais o período produtivo das plantas, quando comparados com a região Sudeste.

A temperatura é outro fator climático que apresenta influência no crescimento vegetativo e produtivo do maracujazeiro (Ishihata, 1983; Menzel et al., 1987; Utsunomiya, 1992).

Em Kyoto, Japão, estudos realizados por Utsunomiya (1992) mostraram o efeito da temperatura no crescimento, florescimento, peso médio e rendimento de suco em plantas de maracujá roxo, sendo os maiores valores, encontrados nas temperaturas diurna e noturna de $28^{\circ} \mathrm{C}$ e $23^{\circ} \mathrm{C}$, respectivamente. O florescimento ocorreu praticamente na mesma época em todas as combinações de temperaturas diurna/noturnas testadas $\left(23 / 18^{\circ} \mathrm{C}, 28 / 23^{\circ} \mathrm{C}, 33 / 28^{\circ} \mathrm{C}\right)$ enquanto o período final prolongou-se por mais 7 , 8 e 16 dias em temperaturas diurnas de $33^{\circ} \mathrm{C}, 28^{\circ} \mathrm{C}$ e $23^{\circ} \mathrm{C}$ respectivamente. Apesar de todos os botões florais se manterem nos ramos até a antese, em todas as temperaturas 
avaliadas, nas temperaturas mais elevadas foi constatada maior queda de flores logo após a polinização, resultando em maiores produções nas menores temperaturas. Ishihata (1983) justifica que a queda precoce das flores está relacionada com a baixa germinação do pólen; segundo o autor, para o maracujazeiro roxo, temperaturas entre $25^{\circ} \mathrm{C}$ e $30^{\circ} \mathrm{C}$ foram ótimas para a germinação do pólen, sendo que nas temperaturas de $15^{\circ} \mathrm{C}$ e $35^{\circ} \mathrm{C}$ esta praticamente não ocorre.

Além disso, temperaturas mais elevadas podem provocar a queda de frutos pela inibição da fertilidade do óvulo, ou mais tarde, por ocasião do desenvolvimento da semente, resultando em um menor número de sementes por fruto. Portanto, apesar do desenvolvimento vegetativo vigoroso, temperaturas superiores a $33^{\circ} \mathrm{C}$ afetam negativamente o crescimento e o peso dos frutos, além do rendimento em volume de suco (Utsunomiya, 1992).

Na região Centro-Oeste do país, Veras (1997) também constatou que mesmo com desenvolvimento vegetativo vigoroso, temperaturas superiores a $33^{\circ} \mathrm{C}$ levam a formação de frutos pequenos com menor rendimento de suco. $\mathrm{O}$ peso do fruto foi significativamente maior com temperaturas variando entre $13^{\circ} \mathrm{C}$ e $28^{\circ} \mathrm{C}$ em relação a $33^{\circ} \mathrm{C}$ com pequena diferença entre $23^{\circ} \mathrm{C}$ e $28^{\circ} \mathrm{C}$. O peso da casca foi maior sob baixas temperaturas, enquanto o peso do suco foi maior na temperatura de $28^{\circ} \mathrm{C}$. O efeito no florescimento é intensificado em períodos de temperaturas moderadamente altas, devido à interação entre temperatura e radiação solar (Menzel et al., 1987).

O efeito da temperatura sobre o maracujazeiro também é refletido na absorção de nutrientes, conforme constatado por Menzel et al. (1987), quando observaram que o acúmulo máximo de nutrientes na parte aérea das plantas ocorreu com temperaturas diurna e noturna em torno de $25^{\circ} \mathrm{C}$ e $20^{\circ} \mathrm{C}$, respectivamente. Os níveis de potássio aumentaram com o aumento da temperatura, enquanto, nitrogênio, enxofre e magnésio reduziram.

Outra condição climática que influência o ciclo produtivo do maracujazeiro é a radiação solar. Para Menzel \& Simpson (1988) a radiação solar é o fator ambiental que mais contribui para as flutuações de florescimento e a formação de frutos de 
maracujazeiro. Esses autores verificaram que plantas submetidas a baixas radiações (de 2,1 a 6,3 $\mathrm{MJ} \mathrm{m}^{-2} \mathrm{~d}^{-1}$ ) apresentaram maior comprimento do ramo; quando a radiação solar global incidente foi elevada para 20,9 $\mathrm{MJ} \mathrm{m}^{-2} \mathrm{~d}^{-1}$, a área foliar, o número de botões florais, o número de flores abertas e o peso da matéria seca aumentaram. Os autores acrescentam que períodos intermitentes de uma a quatro semanas de forte sombreamento, durante um período de pleno sol, induzem efeito residual sobre o crescimento, florescimento e o potencial produtivo da cultura, e relatam que períodos de alta nebulosidade nas regiões tropicais influenciam a produtividade do maracujazeiro, principalmente se o sombreamento ocorrer logo após um período de alto vingamento de frutos, devido à competição entre gemas florais e frutos em desenvolvimento. $\mathrm{O}$ mesmo raciocínio é utilizado por Vasconcellos \& Duarte Filho (2000) para justificar a baixa produção por planta nos plantios adensados, já que o sombreamento natural dos ramos diminui o ganho fotossintético das plantas.

\subsection{Unidades térmicas}

A duração de cada estádio vegetativo de uma cultura varia com a espécie e as condições climáticas. Diversos elementos climáticos condicionam o desenvolvimento das espécies agrícolas, sendo as condições térmicas e hídricas os dois parâmetros ambientais que mais afetam o estabelecimento e o desenvolvimento das culturas. Em cultivos irrigados, as condições térmicas assumem maior importância, já que as necessidades hídricas são supridas pela irrigação (Mota, 1986).

Existem vários métodos que relacionam o grau de desenvolvimento de uma cultura com a temperatura do ar, sendo o mais empregado o das unidades térmicas ou graus-dia. O conceito de graus-dia pressupõe a existência de temperaturas-base mínima e máxima; sendo a temperatura ambiente menor ou maior, respectivamente, a planta não se desenvolve, ou se desenvolve a taxas reduzidas. Cada espécie vegetal ou cultivar possui uma temperatura-base, que pode variar em função da fase fenológica da planta,

sendo comum, no entanto, a adoção de um valor médio único para todo o ciclo da 
cultura, por ser mais fácil sua aplicação (Camargo, 1984). De acordo com Varejão (2000), quando se conhecem os valores em graus-dia necessários para completar cada estádio fenológico de determinada cultura (constante térmica) e as temperaturas máximas e mínimas diárias esperadas (valores médios) em determinada área, pode-se estimar, com facilidade, a duração do ciclo, bem como estabelecer a época de plantio em função da época mais apropriada para a colheita.

No que se refere à cultura do maracujazeiro, não se conhecem estudos procurando determinar a sua temperatura basal mínima (Tb) e máxima (TB). Entretanto, de acordo com Piza Júnior (1998), observações preliminares têm indicado que esses valores estão em torno de $8^{\circ} \mathrm{C}$ e $27^{\circ} \mathrm{C}$. Melo (2001), utilizando estes valores, encontrou um acúmulo de energia térmica de 6545 graus-dia no primeiro ano da cultura.

\subsection{Déficit hídrico e Irrigação}

A cultura do maracujazeiro é reportada em diversos estudos como exigente em umidade no solo para o pleno sucesso no desenvolvimento e na produção de frutos (Menzel et al.,1986; Stavely \& Wolstenholme,1990 ). Sendo assim, a irrigação vem sendo reconhecida como parte fundamental do manejo da cultura, não somente como condição essencial, principalmente em regiões subúmidas e semi-áridas, mas também como alternativa de produção na entressafra, em regiões onde a precipitação é insuficiente (Veras, 1997; Coelho, 1999).

O estresse hídrico na cultura do maracujazeiro amarelo foi estudado por Menzel et al. (1986), que verificaram a redução no tamanho dos ramos, que apresentaram menor número de nós e comprimento de entrenós, refletindo conseqüentemente, no número de botões florais e flores abertas. Observaram também, a redução da área foliar decorrente da diminuição do tamanho e do número de folhas, resultando na redução da matéria seca total e no aumento da proporção de matéria seca das raízes em relação ao caule e às folhas. Ruggiero et al. (1996) acrescentam que o estresse hídrico pode, também, provocar a queda de folhas e frutos, principalmente no início do seu desenvolvimento; 
os frutos, quando se formam, podem crescer com enrugamento, prejudicando a qualidade da produção. Menzel et al. (1986) atribuem essas mudanças morfológicas à redução na absorção de nutrientes, além da redução do potencial de água na folha, concluindo que nas condições do estudo, tensões de água no solo inferiores a - $0,01 \mathrm{MPa}$ podem limitar o crescimento vegetativo e o potencial de produção da cultura, indicando a necessidade da irrigação para manter o solo na capacidade de campo (-0,0009 MPa), no período de florescimento.

Em estudo similar com o maracujazeiro roxo, Stavely \& Wolstenholme (1990) encontraram resultados que apoiaram os encontrados por Menzel et al. (1986), sugerindo que o potencial de água no solo não deve exceder -0,02 MPa durante os períodos críticos de diferenciação floral e frutificação. Estes autores recomendam que no período de diferenciação floral a irrigação deve ser realizada quando o potencial de água do solo for de $-0,015 \mathrm{MPa}$, que correspondeu a aproximadamente $80 \%$ da capacidade de campo do solo estudado pelos pesquisadores.

$\mathrm{O}$ método de irrigação mais adequado para o maracujazeiro tem sido a irrigação localizada, principalmente o sistema por gotejamento, pois proporciona a aplicação de água e nutrientes junto à região de maior concentração de raízes, permite o controle da umidade e não molha a parte aérea das plantas, reduzindo a incidência de doenças (Ruggiero et al., 1996).

Esse sistema foi utilizado por Martins (1998) em dois experimentos com lâminas de irrigação e doses de nutrientes. No primeiro experimento, com doses de nitrogênio, observou-se que a lâmina de irrigação baseada em $75 \%$ da evaporação do tanque classe A, proporcionou a maior largura da copa $(0,90 \mathrm{~m})$ e a maior produtividade total (46892 $\mathrm{kg} \mathrm{ha}^{-1}$ ), quando combinado com a dose de nitrogênio de $250 \mathrm{~g} \mathrm{planta}^{-1}$ ano $^{-1}$, totalizando $1293 \mathrm{~mm}$ de água pela irrigação e precipitação. No segundo experimento a lâmina baseada em $100 \%$ da evaporação do tanque classe $\mathrm{A}$, combinada com a dose de potássio de $531 \mathrm{~g} \mathrm{planta}^{-1}$ ano $^{-1}$, foi a que proporcionou a maior produtividade (43526 kg $\mathrm{ha}^{-1}$ ), totalizando o consumo hídrico de $1319 \mathrm{~mm}$.

Em outro experimento com lâminas de irrigação e doses de potássio, Sousa (2000) verificou que a aplicação de água equivalente a 75\% do consumo hídrico 
determinado a partir de lisímetros de drenagem com a dose de potássio de $0,45 \mathrm{~kg}$ de $\mathrm{K}_{2} \mathrm{O}$, proporcionou a maior produtividade da cultura $\left(45454 \mathrm{~kg} \mathrm{ha}^{-1}\right)$, totalizando o consumo hídrico de $2110 \mathrm{~mm}$, considerando irrigação e precipitação. No segundo ano de produção do mesmo experimento, Lucas (2002) encontrou os maiores valores de produtividade $\left(14806 \mathrm{~kg} \mathrm{ha}^{-1}\right)$ para a lâmina correspondente a $54 \%$ da evapotranspiração da cultura.

Melo (2001) também verificou efeito significativo da irrigação na produtividade da primeira safra da cultura do maracujazeiro-amarelo, obtendo $28180 \mathrm{~kg} \mathrm{ha}^{-1}$ com uma lâmina baseada na reposição de $100 \%$ da água evapotranspirada, combinado com a dose de $475 \mathrm{~kg} \mathrm{~N} \mathrm{ha}^{-1}$ ano $^{-1}$, totalizando $533 \mathrm{~mm}$ de irrigação e precipitação.

\subsection{Evapotranspiração}

A água é o elemento essencial ao metabolismo vegetal, pois participa principalmente da constituição celular e do processo de fotossíntese. A planta, todavia, transfere para a atmosfera cerca de $98 \%$ da água retirada do solo. Por isto, o consumo de água das plantas normalmente se refere à água perdida pela evaporação (Ev) da superfície do solo e pela transpiração $(\mathrm{T})$. Esses processos, embora independentes, ocorrem simultaneamente dando origem ao termo evapotranspiração (ET) (Pereira et al., 1997).

O conceito de evapotranspiração foi introduzido pela primeira vez por Thornthwaite et al. (1944), citado por Camargo (1962), nos Estados Unidos, como sendo a ocorrência simultânea dos processos de evaporação e de transpiração, numa superfície vegetada. Alguns anos mais tarde, Thornthwaite (1948) definiu como potencial (ETp) a evapotranspiração que ocorre nas seguintes condições de contorno: extensa superfície vegetada cobrindo totalmente o solo, em crescimento ativo e sem restrição hídrica, de modo que somente o balanço vertical de energia interfira no processo. Quase que simultaneamente, Penman (1948), na Inglaterra, também definiu a ETp, ressaltando que a vegetação deveria ser baixa e com altura uniforme. 
A definição do termo evapotranspiração de referência (ETo) surgiu no início dos anos 70 , visto que as definições originais, embora definidas corretamente, não especificavam o tipo de vegetação, o grau e a altura da cobertura vegetal do solo, as dimensões da superfície e as condições de bordadura. Wright \& Jensen (1972) sugeriram que a cultura de referência deveria ser a alfafa, em fase de crescimento ativo, com tamanho variando entre 0,3 e $0,5 \mathrm{~m}$ de altura e bordadura mínima de $100 \mathrm{~m}$. Posteriormente, Doorenbos \& Pruitt (1977), definiram como ETo a evapotranspiração que ocorre em uma extensa área de grama com altura de 0,08 a $0,15 \mathrm{~m}$, em crescimento ativo, cobrindo totalmente o solo e sem deficiência de água.

Procurando superar a dificuldade na adoção do coeficiente de cultura determinado a partir de outra cultura de referência, Smith (1991) propôs a adoção de uma definição padronizada para a evapotranspiração de referência, com vistas, principalmente, à utilização do modelo de Penman-Monteith. Portanto, a evapotranspiração de referência seria aquela que ocorre em uma cultura hipotética, com altura fixa de $0,12 \mathrm{~m}$, albedo igual a 0,23 e resistência ao transporte de vapor d'água igual a $69 \mathrm{~s} \mathrm{~m}^{-1}$. Estas características, segundo Sediyama (1996) e Pereira et al. (1997) seria encontrada em um gramado verde, de altura uniforme, em crescimento ativo, cobrindo totalmente a superfície do solo e sem deficiência hídrica.

A evapotranspiração de referência, segundo Burman et al. (1980), pode ser determinada a partir de métodos com medidas diretas (lisímetros e balanço hídrico) e estimativas (fórmulas empíricas, semi empíricas e evaporímetros). A lisimetria é considerada como o único método para determinação da evapotranspiração com o nível de precisão adequado, sendo utilizado na calibração de outros métodos de estimativas. Entretanto, por ser extremamente difícil e onerosa, exigindo a instalação de equipamentos especiais, a sua utilização é limitada.

A metodologia preconizada pela FAO, em seu boletim número 24 (Doorenbos \& Pruitt, 1977), sugeria a estimativa da evapotranspiração da cultura (ETc) a partir da evapotranspiração de referência e do coeficiente de cultura (Kc), utilizando-se como padrão o método de Penman (1948). Essa metodologia, denominada de duas etapas, 
ainda é bastante empregada, porém, atualmente, o novo método estabelecido como padrão pela FAO (Smith, 1991) para se estimar a ETo é o de Penman-Monteith.

O modelo de Penman-Monteith, desenvolvido por Monteith (1965), é um método combinado, desenvolvido a partir da introdução da relação entre a resistência ao fluxo de vapor pela folha $\left(r_{c}\right)$ e a resistência aerodinâmica $\left(r_{a}\right)$ no modelo original de Penman, na tentativa de descrever o papel da turbulência atmosférica no processo de transporte do vapor d'água e as características fisiológicas da planta. A teoria da grande folha ('big leaf") adotada pelo pesquisador, assume que todas as folhas estão expostas às mesmas condições ambientais, embora essa não seja a condição real (Pereira et al., 1997). Essa nova equação, de formulação teórica rigorosamente física que possibilita o entendimento dos processos físicos e biológicos envolvidos na evaporação da água de superfícies vegetadas, passou a ser denominada de Penman-Monteith, sendo adotada como padrão pela FAO a partir de 1991 (Smith, 1991).

A incorporação dos efeitos da área foliar e da altura da vegetação no modelo de Penman-Monteith faz com que este modelo estime com maior precisão a evapotranspiração potencial para uma ampla variedade de climas e localidades (Peres, 1994). Diversas pesquisas, realizadas em várias regiões, comprovaram a superioridade do modelo de Penman-Monteith. Em Kimberly, Idaho, EUA, um estudo avaliando onze métodos climatológicos na estimativa da evapotranspiração de referência, utilizando dados relatados por Jensen (1974) para a cultura da alfafa, mostrou que o método combinado de Penman-Monteith forneceu melhores resultados, quando comparado com valores de evapotranspiração medidos em lisímetros de pesagem (Saad \& Scaloppi, 1988).

No Estado de São Paulo o modelo de Penman-Monteith foi estudado por Peres (1994) na estimativa da ETo em três localidades, originando resultados consistentes e bem correlacionados com os valores medidos em evapotranspirômetros, indicando que o modelo pode ser utilizado com sucesso na determinação das necessidades hídricas das culturas. Em Piracicaba, SP, Sentelhas (1998) também verificou que o método de Penman-Monteith apresentou estimativas melhores da ETo, quando comparado com o 
método de Penman e Priestley-Taylor, utilizando o lisímetro de pesagem como referência.

\subsection{Evapotranspiração da cultura}

A evapotranspiração de referência (ETo) é considerada como um fator básico na determinação do total de água necessária durante o ciclo de uma cultura, quando se deseja um manejo racional da água na prática da irrigação (Santos et al., 1996). Atendose à diferença existente entre a grama em crescimento ativo e outras culturas, em qualquer estádio de desenvolvimento, ambas vegetando sem restrição hídrica, definiu-se evapotranspiração da cultura (ETc) ou evapotranspiração máxima (ETm) (Doorenbos \& Kassam, 1979). Assim, ETc refere-se a perda de água por uma cultura qualquer, em condições de nenhuma restrição hídrica e em qualquer estádio de desenvolvimento.

A evapotranspiração da cultura, geralmente, é determinada a partir de medidas diretas, baseadas no balanço hídrico em volume de solo conhecido. A ETc pode ser obtida a partir do lisímetro, também conhecido como evapotranspirômetro, que é um equipamento constituído de uma caixa impermeável, contendo um volume de solo, que permite conhecer detalhadamente alguns dos termos do balanço de água no volume amostrado (Pereira et al., 1997). Aboukhaled et al. (1982) estudando a lisimetria, também definiram estes equipamentos como sendo recipientes grandes, cheios de solo, enterrados em locais que representam as condições naturais do meio, de superfície desnuda ou coberta com vegetal, utilizados para determinar a evapotranspiração de uma cultura em fase de crescimento, ou uma cobertura vegetal de referência, ou para determinar a evaporação de um solo nu. Para estes autores, os lisímetros podem ser divididos em dois tipos principais: pesáveis e não pesáveis (lisímetro de drenagem e de lençol freático constante). Os lisímetros pesáveis apresentam maior precisão na obtenção de dados diários de evapotranspiração; entretanto, necessitam de equipamentos mais sofisticados, resultando em custos superiores aos demais. 
O lisímetro de drenagem, utilizado inicialmente por Thornthwaite para a determinação da ETo e, posteriormente, empregado por Camargo (1962) no Estado de São Paulo, é um equipamento que se baseia no princípio de conservação de massa para a água num volume de solo. De acordo com Camargo (1971), os lisímetros de drenagem são grandes vasos com paredes impermeáveis enterrados até o nível do solo e plantados com vegetação idêntica à do terreno circundante, constituindo amostra representativa da área vegetada. $\mathrm{O}$ autor ainda cita que nesse tipo de lisímetro, as irrigações devem ser diárias ou a cada dois dias de modo a provocar pequeno percolado. Esse tipo de lisímetro apresenta limitação na obtenção de dados diários (Silva, 1996), sendo normalmente utilizado para a obtenção de dados decendiais (Camargo, 1962).

Um outro tipo de lisímetro, bastante utilizado, é o de lençol freático constante, que adota um sistema automático de alimentação e registro da água reposta de modo a manter o nível do lençol freático constante, sendo a evapotranspiração diretamente proporcional à água que sai do sistema de alimentação (Assis, 1978). Esse tipo de lisímetro vem sendo o mais utilizado, atualmente, na determinação da evapotranspiração e do coeficiente de cultura (Pereira et al., 1995).

$\mathrm{Na}$ literatura, poucos são os trabalhos sobre o estudo da evapotranspiração da cultura do maracujazeiro. Silva (2001) utilizando um lisímetro com nível freático constante determinou a evapotranspiração da cultura do maracujazeiro amarelo, em condições protegidas, no primeiro ano de produção, na região de Botucatu, SP. O estudo mostrou que a cultura apresenta maior demanda hídrica nos estádios correspondentes à floração, formação e maturação dos frutos com valores variando entre 2,32 mm e 3,21 $\mathrm{mm} \mathrm{d}^{-1}$, que ocorreram entre 140 e 210 dias após o transplantio. Em outro estudo com a cultura do maracujazeiro amarelo, em Piracicaba, SP, Alencar (2000), utilizando lisímetros de drenagem, já havia verificado o aumento da evapotranspiração da cultura com o aumento da área foliar, encontrando o valor de $4,68 \mathrm{~mm} \mathrm{~d}^{-1}$ no início da floração e frutificação, correspondendo ao período entre 182 e 196 dias após o transplantio. As diferenças entre os valores de demanda hídrica da cultura nos dois experimentos são justificadas por Silva (2001) como decorrente das diferenças entre as épocas de plantio, das características fisiológicas inerentes das variedades e das condições edafoclimáticas. 


\subsection{Coeficiente de cultura (Kc)}

O coeficiente de cultura $(\mathrm{Kc})$, como citado anteriormente, é utilizado na metodologia recomendada pela FAO para a estimativa da evapotranspiração da cultura (Doorenbos \& Pruitt, 1977). Este é um coeficiente adimensional, proposto inicialmente por Van Wilk \& De Vries (1954), citado por Melo (2001), calculado pela razão entre a evapotranspiração máxima de uma cultura e a evapotranspiração de referência.

Os coeficientes de cultura variam com as características específicas de cada cultura, estádio de desenvolvimento, época de plantio, densidade de plantio, duração da estação de crescimento, condições de umidade e clima (Doorenbos \& Pruitt, 1977). Sedyiama (1987), acrescenta que o coeficiente de cultura pode variar, também, com a textura e umidade do solo e com a profundidade e densidade radicular. Já Villa Nova (1983) enfatiza que o índice de área foliar é a principal característica que pode resultar em diferentes valores de coeficientes de cultura. Para a maioria das culturas, os coeficientes de cultura, segundo Doorenbos \& Kassan (1979), assumem valores baixos na fase da emergência, valores máximos durante o período de desenvolvimento vegetativo e declinam na fase de maturação.

$\mathrm{Na}$ cultura do maracujazeiro amarelo, poucos estudos foram realizados com o objetivo de determinar o coeficiente de cultura nos diferentes estádios de desenvolvimento das plantas. Porém, de acordo com Millo \& Cunha (1982), o maracujazeiro amarelo em pleno desenvolvimento, no espaçamento de plantio de $3 \mathrm{x}$ $3 \mathrm{~m}$, apresenta uma área sombreada de $40 \%$ e um coeficiente de cultura de 0,8 . Martins (1998) em seu experimento com lâminas de irrigação na cultura do maracujazeiro, realizou o balanço de água no solo, considerando um Kc de 0,4 nos primeiros 60 dias após o transplantio das mudas (DAT), 0,6 no período correspondente à formação da cultura (61 a 120 DAT) e 0,75 a partir dos 120 DAT, correspondendo ao período de florescimento e frutificação.

Em pesquisa sobre o consumo de água do maracujazeiro amarelo, Alencar (2000) observou que o coeficiente de cultura médio até 69 DAT foi de 0,4. A partir deste período o Kc aumentou e atingiu o valor máximo de 1,10 no final do experimento (189 DAT), correspondendo ao início do florescimento da cultura. Em condições protegidas 
Silva (2001) observou a variação do coeficiente de cultivo no primeiro ano de produção do maracujazeiro amarelo, encontrando o valor inicial próximo ao obtido por Alencar (2000). Os maiores valores de Kc observados ocorreram no período correspondente à floração, formação e maturação dos frutos (140 a 230 DAT) com valores próximos a 1,0. Estudando a adequação de coeficientes de cultura no maracujazeiro amarelo, Melo (2001) utilizou valores pré-estabelecidos durante os estádios de desenvolvimento da cultura, verificando que a adoção de 0,4 na fase de crescimento inicial, 0,6 na fase de crescimento vegetativo apical, 0,7 na fase de crescimento vegetativo lateral e 0,8 na fase de floração e maturação dos frutos promoveram a elevação da umidade do solo próximo à capacidade de campo. 


\section{MATERIAL E MÉTODOS}

\subsection{Caracterização da área experimental}

O experimento foi realizado no Campo Experimental da Fazenda Areão, pertencente ao Departamento de Engenharia Rural da Escola Superior de Agricultura "Luiz de Queiroz", ESALQ/USP, localizado no município de Piracicaba, SP, à latitude de $22^{\circ} 42^{\prime} 30$ " S, longitude $47^{\circ} 38^{\prime} 00^{\prime}$ ' W e altitude $576 \mathrm{~m}$.

O clima, segundo a classificação de Köeppen, é do tipo Cwa, ou seja, subtropical úmido com estiagem no inverno, precipitação pluviométrica média de $1247 \mathrm{~mm}$, temperatura média de $21,1^{\circ} \mathrm{C}$, umidade relativa de $74 \%$ e velocidade do vento de $2,2 \mathrm{~m}$ $\mathrm{s}^{-1}$. O solo foi classificado como Terra Roxa Estruturada (Alfisol) série Luiz de Queiroz, com declividade média de $2,3 \%$.

A evapotranspiração da cultura do maracujazeiro amarelo (Passiflora edulis Sims f. flavicarpa Deg) foi determinada utilizando-se 4 lisímetros de drenagem, instalados no centro de uma área experimental (Figura 1) que foi utilizada por Sousa (2000) e Lucas (2002) no estudo de lâminas de irrigação e doses de adubação potássica na cultura do maracujazeiro. Os valores da evapotranspiração da cultura no período inicial de desenvolvimento (21/05/1999 a 16/11/1999), apresentados por Alencar (2000), foram reapresentados neste estudo, a fim de se obter o consumo hídrico da cultura durante todo o período de desenvolvimento, bem como o coeficiente de cultura nos diferentes estádios fenológicos.

Para a confecção dos lisímetros, utilizou-se reservatórios com volume de $1 \mathrm{~m}^{3} \mathrm{e}$ dimensões de $1,25 \mathrm{~m}$ de diâmetro e $0,85 \mathrm{~m}$ de altura, atendendo a 
região de maior volume de raízes, que é de $0,60 \mathrm{~m}$ a partir do tronco e de 0,30 a 0,45 m de profundidade (Medina et al., 1980; Manica, 1981; Kliemann et al., 1986). A drenagem do sistema foi realizada através de uma tubulação de $50 \mathrm{~mm}$ conectada à base do reservatório e à um tubo de $400 \mathrm{~mm}$, utilizado como poço de armazenamento, dando acesso à superfície do solo (Figura 2).

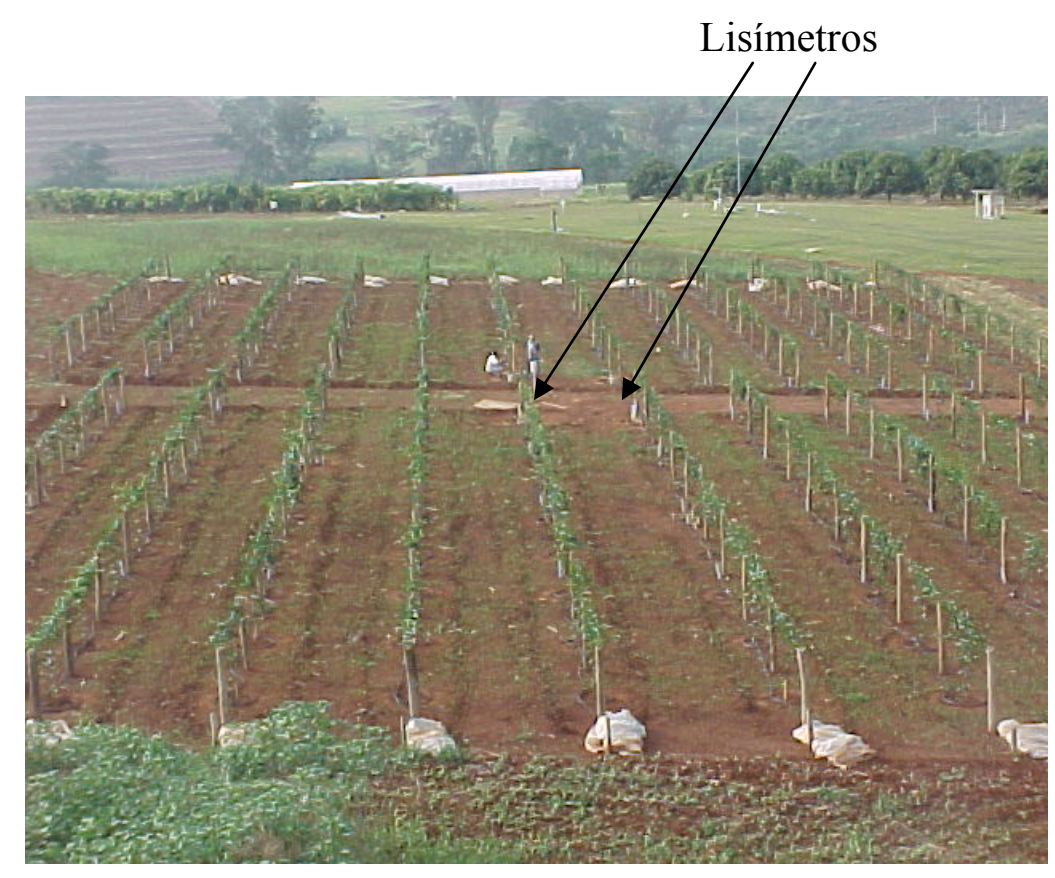

Figura 1 - Vista aérea da área experimental e localização dos lisímetro de drenagem

Para a instalação dos lisímetros na área experimental, foram abertas trincheiras circulares separando-se o solo de acordo com seus horizontes. Antes de iniciar a reposição do solo, obedecendo à ordem dos horizontes, colocou-se uma camada de 0,05 $\mathrm{m}$ de pedra britada, revestida com manta bidin, evitando-se a obstrução da saída por partículas de argila. Após 6 meses da instalação dos lisímetros, foram coletadas amostras de solo nas camadas de 0 a $0,20 \mathrm{~m}, 0,20$ a $0,40 \mathrm{~m}$ e 0,40 a $0,60 \mathrm{~m}$ para caracterização física (Tabelas 1 e 2) e confecção das curvas de retenção da água no solo (Figura 3), ajustada pelo modelo de Van Genuchten (1980), representada na Tabela 3. 


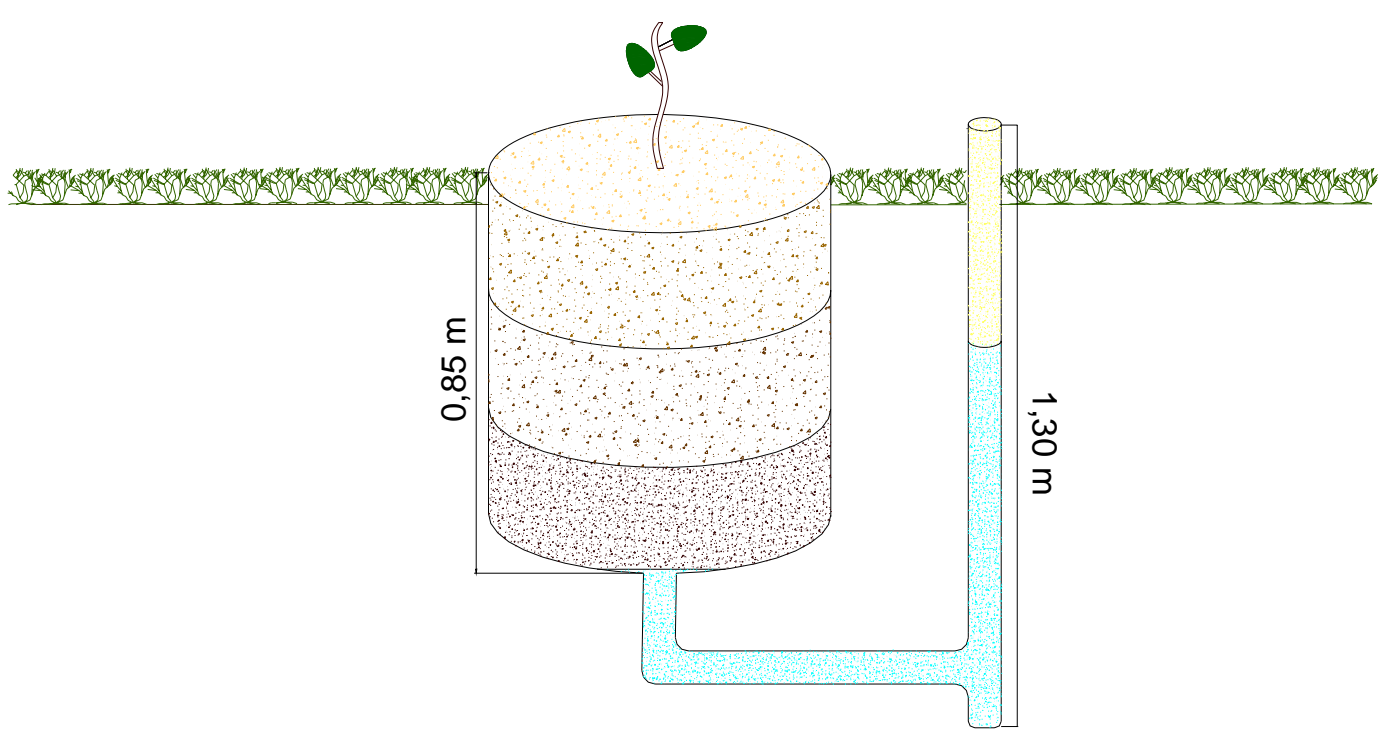

Figura 2 - Desenho esquemático do lisímetro com o sistema de drenagem

Tabela 1. Valores de densidade global do solo $\left(\mathrm{g} \mathrm{cm}^{-3}\right)$ dentro dos lisímetros

\begin{tabular}{cccc}
\hline Lisímetro & \multicolumn{3}{c}{ Camadas $(\mathrm{m})$} \\
& $0-0,20$ & $0,20-0,40$ & $0,40-0,60$ \\
\hline 1 & 1,10 & 1,13 & 1,37 \\
2 & 1,06 & 1,30 & 1,05 \\
3 & 1,06 & 1,18 & 1,37 \\
4 & 1,20 & 1,35 & 1,30 \\
\hline
\end{tabular}

Tabela 2. Análise granulométrica das amostras de solo dentro dos lisímetros

\begin{tabular}{ccccc}
\hline Lisímetro & Camada & Areia (\%) & $\begin{array}{c}\text { Granulometria } \\
\text { Silte (\%) }\end{array}$ & Argila (\%) \\
\hline \multirow{3}{*}{1} & $0,00-0,20$ & 30,2 & 15,5 & 54,3 \\
& $0,20-0,40$ & 26,3 & 14,5 & 59,2 \\
& $0,40-0,60$ & 25,1 & 15,0 & 59,9 \\
2 & $0,00-0,20$ & 29,0 & 20,1 & 50,9 \\
& $0,20-0,40$ & 23,7 & 21,0 & 55,4 \\
& $0,40-0,60$ & 18,7 & 19,1 & 62,2 \\
3 & $0,00-0,20$ & 26,6 & 22,4 & 51,0 \\
& $0,20-0,40$ & 25,6 & 20,1 & 54,3 \\
\multirow{3}{*}{4} & $0,40-0,60$ & 18,6 & 18,5 & 62,9 \\
& $0,00-0,20$ & 25,4 & 20,0 & 54,6 \\
& $0,20-0,40$ & 24,0 & 13,1 & 63,0 \\
& $0,40-0,60$ & 18,5 & 16,8 & 64,8 \\
\hline
\end{tabular}


Lisímetro 1

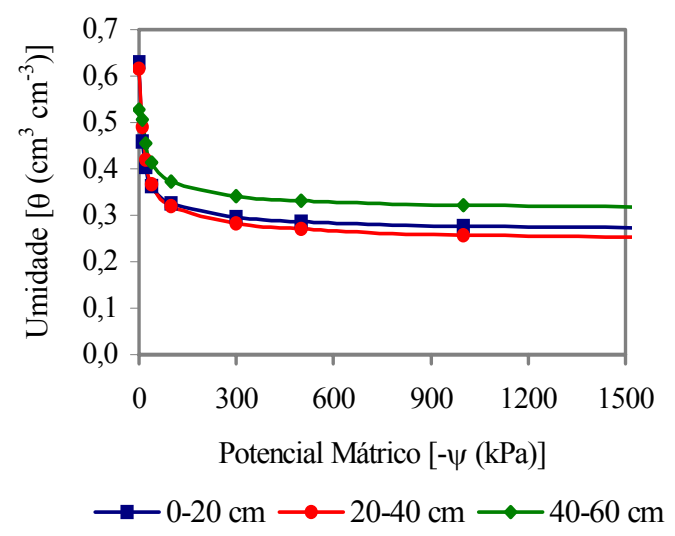

Lisímetro 3

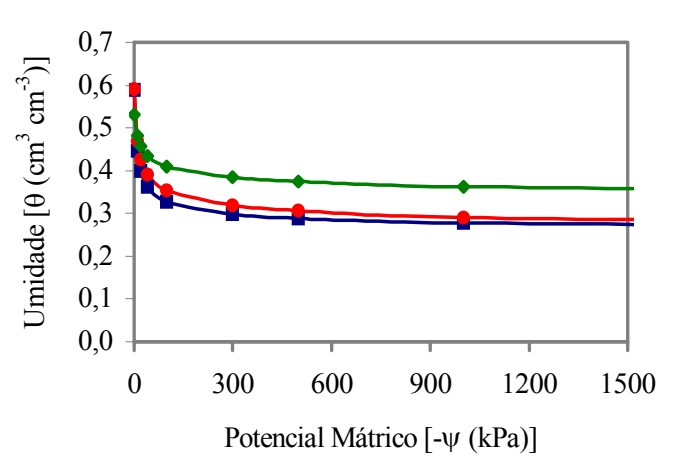

$\longrightarrow 0-20 \mathrm{~cm} \longrightarrow 20-40 \mathrm{~cm} \longrightarrow 40-60 \mathrm{~cm}$
Lisímetro 2

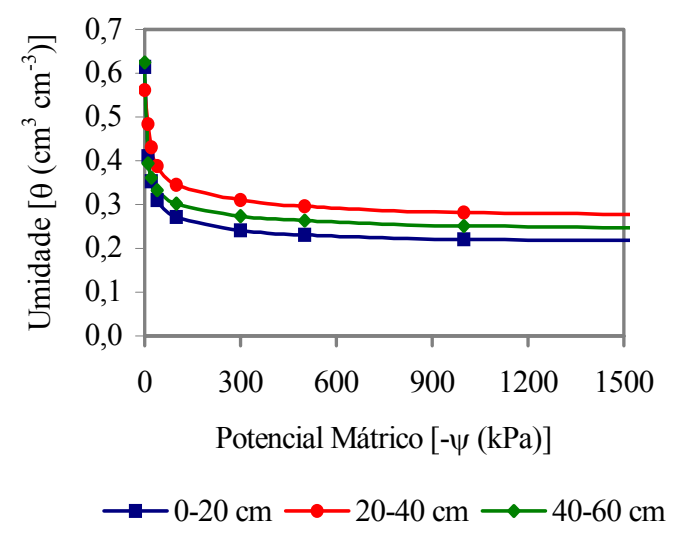

Lisímetro 4

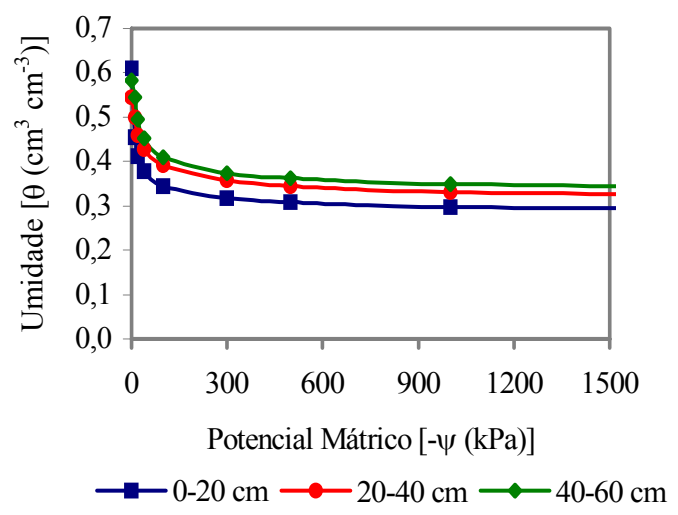

Figura 3 - Curvas de retenção de água no solo nos 4 lisímetros, em três profundidades 
Tabela 3. Parâmetros de ajuste da curva de retenção de van Genuchten (1980)

\begin{tabular}{ccccccc}
\hline Lisímetro & Camada & $\begin{array}{c}\theta_{\mathrm{s}} \\
\left(\mathrm{cm}^{3} \mathrm{~cm} \mathrm{-}^{3}\right)\end{array}$ & $\begin{array}{c}\theta_{\mathrm{r}} \\
\left(\mathrm{cm}^{3} \mathrm{~cm}^{3}\right)\end{array}$ & $\begin{array}{c}\alpha \\
\mathrm{cm}^{-1}\end{array}$ & $\mathrm{~m}$ & $\mathrm{n}$ \\
\hline \multirow{3}{*}{1} & $0,00-0,20$ & 0,629 & 0,247 & 0,3844 & 0,1071 & 4,0706 \\
& $0,20-0,40$ & 0,616 & 0,222 & 0,2406 & 0,0820 & 5,3802 \\
& $0,40-0,60$ & 0,528 & 0,290 & 0,1179 & 0,0759 & 5,6150 \\
\multirow{2}{*}{2} & $0,00-0,20$ & 0,614 & 0,193 & 0,4420 & 0,1210 & 3,6872 \\
& $0,20-0,40$ & 0,561 & 0,228 & 0,2158 & 0,0582 & 5,8105 \\
& $0,40-0,60$ & 0,624 & 0,190 & 1,7693 & 0,1019 & 2,5939 \\
\multirow{3}{*}{3} & $0,00-0,20$ & 0,589 & 0,242 & 0,3950 & 0,1025 & 3,7182 \\
& $0,20-0,40$ & 0,590 & 0,217 & 0,4392 & 0,0746 & 3,5565 \\
\multirow{4}{*}{4} & $0,40-0,60$ & 0,532 & 0,282 & 0,3189 & 0,0469 & 4,1579 \\
& $0,00-0,20$ & 0,611 & 0,262 & 0,5057 & 0,0980 & 3,7568 \\
& $0,20-0,40$ & 0,545 & 0,250 & 0,1990 & 0,0463 & 5,3292 \\
& $0,40-0,60$ & 0,584 & 0,301 & 0,1391 & 0,1019 & 3,5598 \\
\hline
\end{tabular}

\subsection{Manejo da Cultura}

O preparo do solo consistiu de uma aração e duas gradagens com posterior aplicação e incorporação de $2000 \mathrm{~kg} / \mathrm{ha}$ de calcário dolomítico, 60 dias antes do transplantio das mudas, para elevação da saturação por bases à 80\% (Rizzi et al., 1998). As covas, abertas no espaçamento de 3,5 m x 4,0 m, possuindo dimensões de 0,60 m de diâmetro e $0,60 \mathrm{~m}$ de profundidade receberam $40 \mathrm{~L}$ de esterco de curral curtido como fonte de matéria orgânica, 0,20 $\mathrm{kg} \mathrm{P}_{2} \mathrm{O}_{5}$ na forma de superfosfato simples, 0,004 $\mathrm{kg} \mathrm{Zn}$ na forma de sulfato de zinco e $0,001 \mathrm{~kg} \mathrm{~B}$ tendo como fonte o ácido bórico. As adubações de formação e de produção, com nitrogênio e potássio, seguiram a recomendação de Melleti \& Maia (1999), sendo realizadas através da água de irrigação na freqüência de 7 dias, de acordo com a curva de absorção de nutrientes do maracujazeiro (Haag et al., 1973). Na fase de formação da cultura (até 120 dias após o transplantio), aplicou-se $0,10 \mathrm{~kg} \mathrm{~N}_{\text {planta }}{ }^{-1}$ na forma de uréia e $0,05 \mathrm{~kg} \mathrm{~K}_{2} \mathrm{O}$ planta $^{-1}$ na forma cloreto de potássio. No período de produção do maracujazeiro, aumentou-se a adubação para $0,38 \mathrm{~kg} \mathrm{~N}_{\text {planta }}{ }^{-1}$ (nitrato de potássio e uréia) e $0,40 \mathrm{~kg} \mathrm{~K}_{2} \mathrm{O}$ planta $^{-1}$, 
tendo como fonte o nitrato de potássio. No segundo ano de produção da cultura, a adubação seguiu a mesma recomendação de nitrogênio e potássio para o período de produção. Neste período, efetuou-se a aplicação de $0,46 \mathrm{~kg}$ de calcário dolomítico e $0,014 \mathrm{~kg} \mathrm{P}_{2} \mathrm{O}_{5}$ na forma de superfosfato simples, além da adubação foliar com $1 \mathrm{ml} \mathrm{L}^{-1}$ de ácido bórico, $0,1 \mathrm{ml} \mathrm{L}^{-1}$ de molibdato de sódio, $3 \mathrm{ml} \mathrm{L}^{-1}$ de sulfato de zinco, $20 \mathrm{ml} \mathrm{L}^{-1}$ de sulfato de magnésio e $5 \mathrm{ml} \mathrm{L}^{-1}$ de sulfato de cobre, de acordo com análise foliar e recomendação de Ruggiero et al. (1996).

As mudas de maracujazeiro foram transplantadas no dia 05 de maio de 1999, 15 dias após o preparo das covas, utilizando a variedade amarela (Passiflora edulis Sims f. flavicarpa Deg), preparadas em bandejas de isopor. As plantas foram conduzidas em espaldeiras verticais, com um fio de arame liso $\mathrm{n}^{0} 12$, preso e esticado por mourões espaçados de quatro metros. No início do desenvolvimento das plantas utilizaram-se fios de barbante com a finalidade de conduzir a haste principal à espaldeira. $\mathrm{Na}$ fase de condução das plantas foram feitas desbrotas periódicas dos ramos laterais, de maneira que se assegurasse o crescimento de uma única haste até a altura próxima do fio de arame; a partir desse ponto, as plantas foram conduzidas com dois ramos laterais crescendo de forma controlada, para facilitar a poda de renovação e as práticas de polinização. Como o maracujazeiro apresentou um crescimento contínuo e vigoroso no primeiro ano de produção, realizou-se uma poda de renovação no período compreendido entre 10/10/00 e 18/10/00 (525 a 533 dias após transplantio), com a finalidade de retirar ramos improdutivos e estimular o maior crescimento vegetativo para o próximo período de produção.

Devido a pouca presença de abelhas mamangavas, principal agente polinizador natural do maracujazeiro amarelo, utilizou-se a prática da polinização artificial, realizada diariamente, de acordo com recomendações descritas em Ruggiero et al. (1996). Realizou-se também, pulverizações com inseticidas e fungicidas de acordo com a necessidade da cultura. $\mathrm{O}$ controle de ervas daninhas foi feito à base de roçagem nas entrelinhas e capinas dentro dos lisímetros e nas linhas de plantio, mantendo as plantas do maracujazeiro sempre isentas da competição com plantas invasoras (Figura 4). 


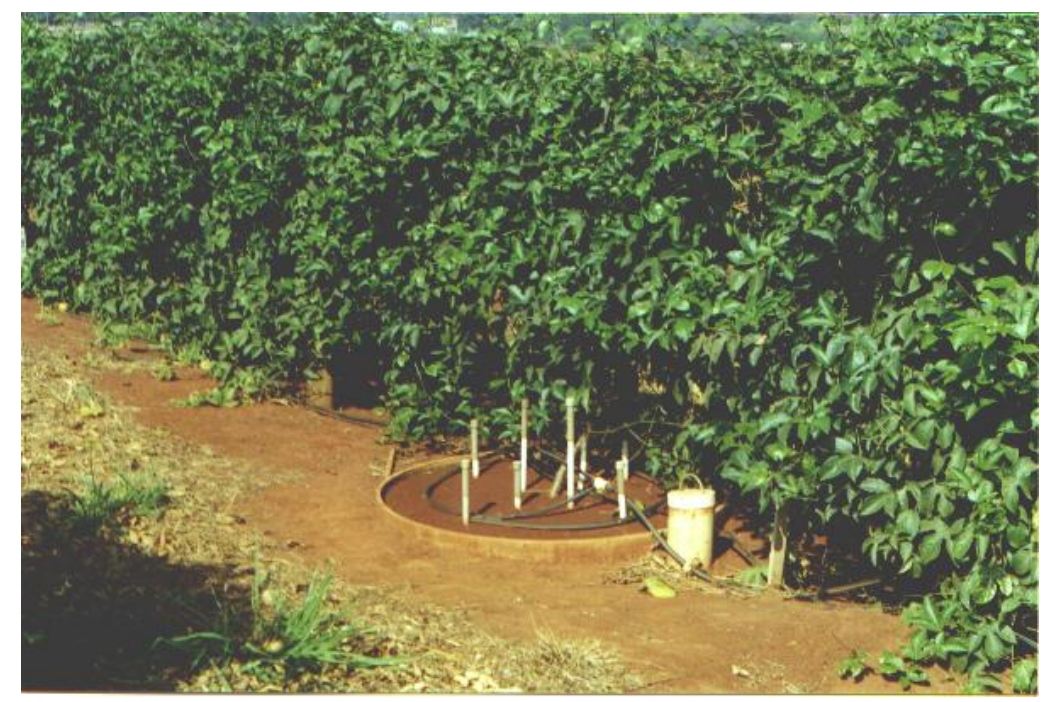

Figura 4 - Detalhe das linhas de plantio e do lisímetro isento de ervas daninhas

Devido a possibilidade de ocorrência de baixas temperaturas durante o inverno, no período de 05/06/99 (32 DAT) a 14/07/99 (71 DAT), as plantas, que ainda se encontravam em crescimento vegetativo inicial, foram protegidas por uma cobertura de plástico, colocada sobre as linhas de plantio, conforme reportado por Alencar (2000) e Sousa (2000).

\subsection{Irrigação}

O sistema de irrigação utilizado foi o gotejamento, com emissores Carborundum de vazão nominal de $4 \mathrm{~L} \mathrm{~h}^{-1}$. As linhas de irrigação que passavam pelos lisímetros possuíam, em cada ponto de emissão, cinco gotejadores, regularmente espaçados, dispostos em uma circunferência de 0,50 m de raio, cujo centro era a planta, obedecendo à região de maior concentração de raízes (Medina et al., 1980; Manica, 1981; Kliemann et al., 1986) (Figura 5).

Dentro de cada lisímetro foram instalados tensiômetros nas profundidades de $0,10 \mathrm{~m}, 0,30 \mathrm{~m}, 0,50 \mathrm{~m}$ e $0,60 \mathrm{~m}$, distanciados a $0,15 \mathrm{~m}$ e $0,45 \mathrm{~m}$ da haste principal. Irrigou-se toda vez que o potencial mátrico, medido por tensímetro digital, na profundidade de 0,30 m atingiu 0,01 MPa pois, de acordo com Menzel et al. (1996), 
valores de potencial de água no solo superiores à $0,01 \mathrm{MPa}$ podem provocar danos no crescimento vegetativo e prejudicar o potencial produtivo da cultura.

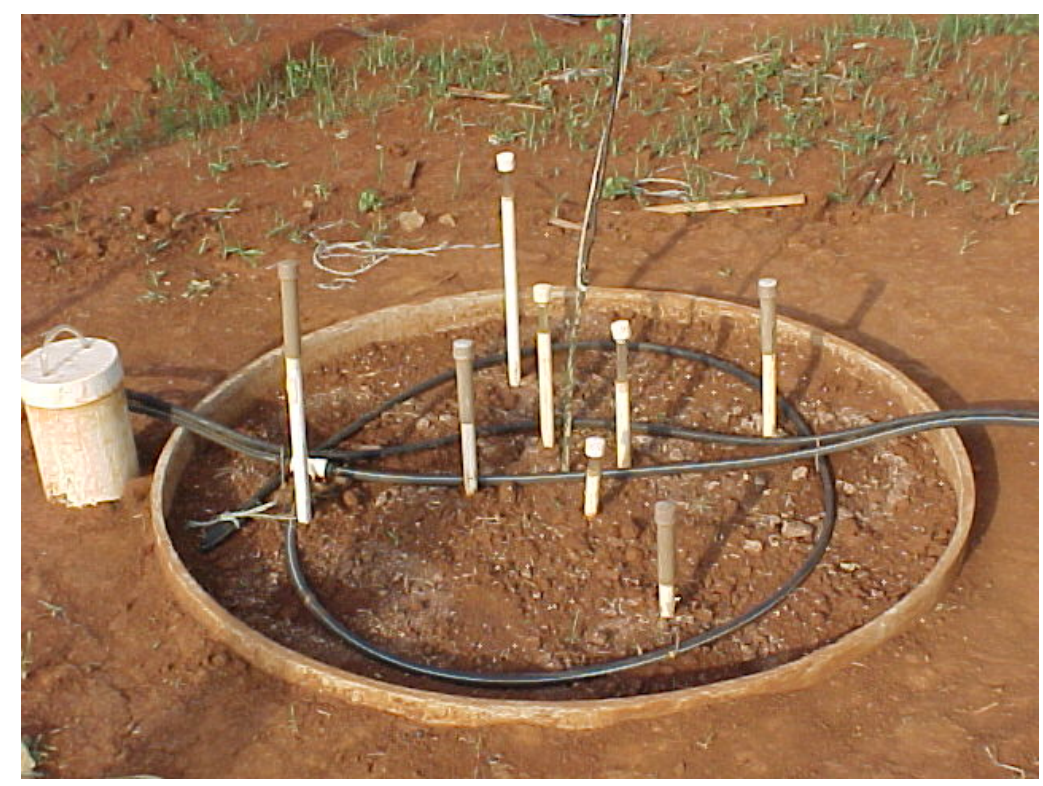

Figura 5 - Detalhe dos lisímetros com o sistema de irrigação, o sistema de drenagem e os tensiômetros

Definido o momento da irrigação, o volume de água foi determinado em função do balanço de água realizado nos lisímetros de drenagem, desconsiderando-se, nesse caso, a variação de armazenamento de água no solo. No cálculo do volume de irrigação necessário considerou-se como entrada de água no lisímetro o volume correspondente à última irrigação e a precipitação pluvial no período. Como saída, considerou-se a drenagem medida no lisímetro a $0,65 \mathrm{~m}$ de profundidade e a evapotranspiração da cultura, utilizando-se uma eficiência de aplicação de água de $90 \%$. Assim, o cálculo do volume total de irrigação necessário por planta, contabilizado no lisímetro, foi feito por:

$$
\mathrm{ITN}=\frac{\mathrm{I}+\mathrm{P}-\mathrm{D}}{0,9}
$$

em que: 
ITN - volume total de irrigação necessário por planta, L;

I - volume de irrigação no último período, L;

$\mathrm{P}$ - volume correspondente à precipitação pluvial, no período, $\mathrm{L}$;

D - volume de água drenada no lisímetro, no período, L.

\subsection{Drenagem}

A água drenada foi coletada por um com conjunto moto-bomba portátil de sucção a vácuo. As medições do volume drenado foram feitas com provetas graduadas em $\mathrm{ml}$.

\subsection{Umidade e variação de armazenamento de água no solo}

A umidade do solo foi determinada a partir das leituras do potencial mátrico da água no solo, medida através dos tensiômetros, e da curva de retenção, ajustada pelo modelo de Van Genuchten (1980), descrito pela equação 2 e representada pela Tabela 3 e Figura 3.

$$
\theta=\theta_{\mathrm{r}}+\frac{\left(\theta_{\mathrm{s}}-\theta_{\mathrm{r}}\right)}{\left[1+\left(\psi_{\alpha}\right)^{\mathrm{n}}\right]^{\mathrm{m}}}
$$

em que:

$\theta$ - umidade a base de volume, $\mathrm{cm}^{3} \mathrm{~cm}^{-3}$;

$\theta_{\mathrm{r}}$ - umidade residual, $\mathrm{cm}^{3} \mathrm{~cm}^{-3}$;

$\theta_{\mathrm{s}}$ - umidade de saturação, $\mathrm{cm}^{3} \mathrm{~cm}^{-3}$;

$\Psi$ - potencial de água no solo, $\mathrm{cm}$

$\alpha\left(\mathrm{cm}^{-1}\right)$, m e n são parâmetros da equação de Van Genuchten

Após a conversão do potencial matricial em umidade, determinou-se o armazenamento de água no solo e sua variação dentro dos lisímetros, considerando as 
áreas de influência descritas na Figura 6, conforme metodologia utilizada por Alencar (2000).

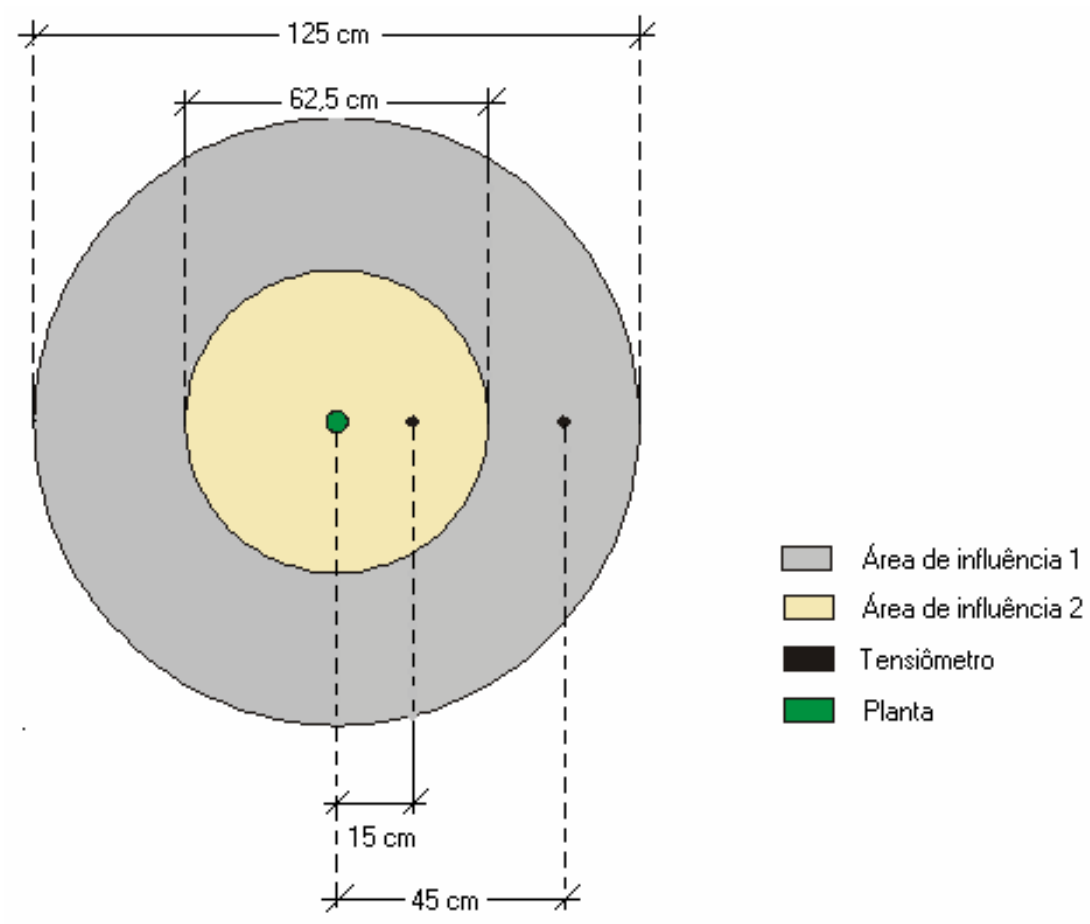

Figura 6 - Desenho esquemático das áreas de influência dos tensiômetros, dentro dos lisímetros

(a) Umidade média por camada

$$
\theta_{\mathrm{m}}=\frac{\theta_{1} \mathrm{~A}_{1}+\theta_{2} \mathrm{~A}_{2}}{\mathrm{~A}_{1}+\mathrm{A}_{2}}
$$

em que:

$\theta_{\mathrm{m}}$ - umidade média, $\mathrm{cm}^{3} \mathrm{~cm}^{-3}$;

$\theta_{1}$ e $\theta_{2}$ - umidades de influência de cada tensiômetro, $\mathrm{cm}^{3} \mathrm{~cm}^{-3}$;

$\mathrm{A}_{1}$ e $\mathrm{A}_{2}$ - área de influência de cada tensiômetro, $\mathrm{cm}^{2}$.

(b) Armazenamento de água no solo 
na primeira camada:

$$
\mathrm{S}_{1}=\theta_{\mathrm{j}} \cdot \mathrm{H}
$$

nas camadas seguintes:

$$
S_{j+1}=\left(\frac{\theta_{j}+\theta_{j+1}}{2}\right) \cdot H
$$

armazenamento no perfil:

$$
\mathrm{S}_{\text {perfil }}=\mathrm{S}_{1}+\sum_{\mathrm{j}=1}^{3} \mathrm{~S}_{\mathrm{j}+1}
$$

em que:

$\mathrm{S}_{1}$ - armazenamento da primeira camada, $\mathrm{mm}$;

$\mathrm{S}_{\mathrm{j}+1}$ - armazenamento das camadas seguintes, $\mathrm{mm}$;

$\mathrm{S}_{\text {perfil - armazenamento do perfil; }}$

$\theta_{\mathrm{j}}$ - umidade da camada atual, $\mathrm{cm}^{3} \mathrm{~cm}^{-3}$;

$\theta_{\mathrm{j}+1}$ - umidade da camada atual mais a umidade da camada seguinte, $\mathrm{cm}^{3} \mathrm{~cm}^{-3}$;

$\mathrm{H}$ - altura da camada, mm.

(c) Variação de armazenamento, L

$$
\Delta \mathrm{S}=\left(\mathrm{S}_{2}-\mathrm{S}_{1}\right) \cdot\left(\mathrm{A}_{1}+\mathrm{A}_{2}\right)
$$

em que:

$\Delta \mathrm{S}$ - variação de armazenamento de água no período de 1 dia, L;

$\mathrm{S}_{1}$ - armazenagem no início do dia $1, \mathrm{~mm}$;

$\mathrm{S}_{2}$ - armazenagem no final do dia $1, \mathrm{~mm}$. 


\subsection{Precipitação}

A água precipitada foi medida por um pluviômetro localizado no centro da área experimental.O volume precipitado dentro dos lisímetros foi determinado a partir da área do mesmo, conforme a equação:

$$
\mathrm{P}=\mathrm{Pp} \cdot\left(\mathrm{A}_{1}+\mathrm{A}_{2}\right)
$$

em que:

$\mathrm{P}$ - precipitação total no período, dentro do lisímetro, L;

$\mathrm{Pp}$ - precipitação coletada no pluviômetro, $\mathrm{mm}$.

\subsection{Determinação da Evapotranspiração da Cultura}

A medida da evaportanspiração da cultura (ETc) em lisímetros constitui um método direto, baseado no princípio da conservação da massa, conforme a seguinte expressão:

$$
\mathrm{ETc}=\mathrm{I}+\mathrm{P}-\mathrm{D} \pm \Delta \mathrm{S}
$$

em que:

ETc - evapotranspiração da cultura no período, $\mathrm{L}_{\text {planta }}{ }^{-1}$;

I - volume total de irrigação no período, L;

$\mathrm{P}$ - precipitação total no período, dentro do lisímetro, L;

D - volume de drenagem no período, L;

$\Delta \mathrm{S}$ - variação do armazenamento de água no período, L.

Para o cálculo da evapotranspiração da cultura, dividiu-se o ciclo da cultura em 31 subperíodos com número de dias superiores a 15, pois, de acordo com Silva (1996), os lisímetros de drenagem apresentam limitação na obtenção de dados diários, sendo recomendados para períodos superiores a 10 dias. Na Tabela 4 são apresentados os 
subperíodos correspondentes ao período de dias após o transplantio das mudas (DAT) e sua relação com a época do ano.

Tabela 4. Subperíodos com os respectivos intervalos de dias, considerados no cálculo da evapotranspiração da cultura

\begin{tabular}{|c|c|c|}
\hline Subperíodo & $\begin{array}{c}\text { Dias após transplantio (DAT) } \\
\text { Lisímetros } 1,2,3 \text { e } 4\end{array}$ & (Dia/mês/ano) \\
\hline 1 & $17-31$ & $21 / 05 / 99$ a $04 / 06 / 99$ \\
\hline 2 & $32-46$ & 05/06/99 a 19/06/99 \\
\hline 3 & $47-61$ & 20/06/99 a 04/07/99 \\
\hline 4 & $62-76$ & 05/07/99 a 19/07/99 \\
\hline 5 & $77-91$ & 20/07/99 a 03/08/99 \\
\hline 6 & $92-106$ & 04/08/99 a 18/08/99 \\
\hline 7 & $107-121$ & $19 / 08 / 99$ a $02 / 09 / 99$ \\
\hline 8 & $122-136$ & 03/09/99 a 17/09/99 \\
\hline 9 & $137-151$ & $18 / 09 / 99$ a $02 / 10 / 99$ \\
\hline 10 & $152-166$ & 03/10/99 a 17/10/99 \\
\hline 11 & $167-181$ & $18 / 10 / 99$ a $01 / 11 / 99$ \\
\hline 12 & $182-196$ & $02 / 11 / 99$ a $16 / 11 / 99$ \\
\hline 13 & $203-219$ & $23 / 11 / 99$ a $09 / 12 / 99$ \\
\hline 14 & $220-238$ & $10 / 12 / 99$ a $28 / 12 / 99$ \\
\hline 15 & $239-270$ & $29 / 12 / 99$ a $29 / 01 / 00$ \\
\hline 16 & $271-286$ & $30 / 01 / 00$ a $14 / 02 / 00$ \\
\hline 17 & $287-308$ & $15 / 02 / 00$ a $07 / 03 / 00$ \\
\hline 18 & $309-329$ & $08 / 03 / 00$ a $28 / 03 / 00$ \\
\hline 19 & $330-352$ & $29 / 03 / 00$ a $20 / 04 / 00$ \\
\hline 20 & $353-369$ & $21 / 04 / 00$ a $07 / 05 / 00$ \\
\hline 21 & $370-390$ & $08 / 05 / 00$ a $29 / 05 / 00$ \\
\hline 22 & $391-414$ & $30 / 05 / 00$ a $22 / 06 / 00$ \\
\hline 23 & $415-441$ & $23 / 06 / 00$ a $19 / 07 / 00$ \\
\hline 24 & $442-463$ & $20 / 07 / 00$ a $10 / 08 / 00$ \\
\hline 25 & $464-492$ & $11 / 08 / 00$ a $08 / 09 / 00$ \\
\hline 26 & $493-525$ & 09/09/00 a $11 / 10 / 00$ \\
\hline 27 & $526-548$ & $12 / 10 / 00$ a $03 / 11 / 00$ \\
\hline 28 & $549-575$ & $04 / 11 / 00$ a $30 / 11 / 00$ \\
\hline 29 & $576-592$ & $01 / 12 / 00$ a $17 / 12 / 00$ \\
\hline 30 & $593-615$ & $18 / 12 / 00$ a $09 / 01 / 01$ \\
\hline 31 & $616-637$ & $10 / 01 / 01$ a $31 / 01 / 01$ \\
\hline
\end{tabular}




\subsection{Evapotranspiração de referência}

A evapotranspiração de referência (ETo) foi estimada pela equação de Penman Monteith, utilizando dados da estação meteorológica do Departamento de Ciências Exatas da ESALQ, localizado a aproximadamente $1000 \mathrm{~m}$ do experimento. Para a estimativa da ETo pelo método de Penman-Monteith, utilizou-se a parametrização apresentada por Smith (1991), baseada nos resultados de Allen et al. (1989), como segue:

$$
\mathrm{ETo}=\frac{\mathrm{s}}{\mathrm{s}+\gamma^{*}}(\mathrm{Rn}-\mathrm{G}) \frac{1}{\lambda}+\frac{\gamma}{\left(\mathrm{s}+\gamma^{*}\right)} \frac{900}{(\mathrm{~T}+275)} \mathrm{U}_{2}\left(\mathrm{e}_{\mathrm{a}}-\mathrm{e}_{\mathrm{d}}\right)
$$

em que: ETo é a evapotranspiração de referência, em $\mathrm{mm} \mathrm{d}^{-1}$; $\mathrm{s}$ é a declividade da curva de pressão de vapor na temperatura média do ar, em $\mathrm{kPa}^{\circ} \mathrm{C}^{-1}$, dado por:

$$
\mathrm{s}=\frac{4098 \mathrm{e}_{\mathrm{s}}}{(\mathrm{T}+237,3)^{2}}
$$

sendo $\mathrm{T}$ a tempepratura média diária, em ${ }^{\circ} \mathrm{C}$;

$\gamma^{*}$ é o coeficiente psicrométrico modificado, em $\mathrm{kPa}{ }^{\circ} \mathrm{C}^{-1}$, dado por:

$$
\gamma^{*}=\gamma\left(1+\frac{\mathrm{r}_{\mathrm{c}}}{\mathrm{r}_{\mathrm{a}}}\right)
$$

Baseando-se nos resultados experimentais de Allen et al. (1989), Smith (1991) sugere que $r_{c} / r_{a}$ seja calculado pela seguinte expressão:

$$
\frac{\mathrm{r}_{\mathrm{c}}}{\mathrm{r}_{\mathrm{a}}}=0,332 \mathrm{U}_{2}
$$

sendo apropriada para a grama com altura média de 0,12 m (Smith, 1991). A variável $U_{2}$ representa a velocidade média do vento $\left(\mathrm{m} \mathrm{s}^{-1}\right)$ medida a $2 \mathrm{~m}$ de altura em relação à superfície do solo. 
Padronizando-se as medidas da velocidade do vento, da temperatura e umidade relativa para uma altura média de $2 \mathrm{~m}$ acima da superfície do solo, e adotando-se uma altura média de 0,12 m para a vegetação, Smith (1991) propõe que o cálculo da resistência aerodinâmica para a grama seja feito pela seguinte expressão:

$$
r_{a}=\frac{208}{U_{2}}
$$

Rn é a radiação líquida em $\mathrm{MJ} \mathrm{m}{ }^{-2} \mathrm{dia}^{-1} ; \mathrm{G}$ é o fluxo de calor no solo, em $\mathrm{MJ} \mathrm{m}^{-2} \mathrm{dia}^{-1}$, sendo considerado igual a zero; $\lambda=2,45 \mathrm{MJ} \mathrm{kg}^{-1}$ é o calor latente de evaporação; $\gamma=$ $0,0622 \mathrm{kPa}^{\circ} \mathrm{C}^{-1}$ é o coeficiente psicrométrico; $\mathrm{T}$ é a temperatura média do ar, em ${ }^{\circ} \mathrm{C}$; $\mathrm{U}_{2 \mathrm{~m}}$ é a velocidade do vento a $20, \mathrm{em} \mathrm{m} \mathrm{s}^{-1} ; \mathrm{e}_{\mathrm{a}}-\mathrm{e}_{\mathrm{d}}$ é o déficit de pressão de vapor, em $\mathrm{kPa}$.

Os valores de Rn foram estimados pelo balanço global de radiação, utilizando a associação das equações de Angströn e de Brunt e albedo (r) igual a 0,23, sugerido por Smith (1991), além da média da $\left(\mathrm{T}_{\max }\right)^{4}$ e $\left(\mathrm{T}_{\min }\right)^{4}$ ao invés de $\left(\mathrm{T}_{\mathrm{med}}\right)^{4}$, segundo proposta do mesmo autor:

$$
\mathrm{Rn}=\mathrm{Qg}(1-\mathrm{r})-\sigma \mathrm{T}^{4}\left(0,56-0,25 \sqrt{\mathrm{e}_{\mathrm{a}}}\right)\left(0,1+0,9 \frac{\mathrm{n}}{\mathrm{N}}\right)
$$

em que: Qg é a irradiância solar global, em MJ m ${ }^{-2} \mathrm{~d}^{-1} ; \sigma=4,8989.10^{-9} \mathrm{MJ} \mathrm{m}^{-2} \mathrm{~d}^{-1} \mathrm{~K}^{-4}$, é a constante de Stefan-Boltzmann; T é a temperatura média absoluta do ar, em K; e é a pressão parcial de vapor da água, em kPa; $\mathrm{n}$ é a insolação, em h; e $\mathrm{N}$ é fotoperíodo, em h, determinado pela equação:

$$
\mathrm{N}=0,1333 \arccos (-\operatorname{tg} \delta \operatorname{tg} \phi)
$$

em que: $\phi=22,7^{\circ}$ é a latitude do local, em graus; $\delta$ é a declinação solar, em graus, determinada a partir de: 


$$
\delta=23,45 \operatorname{sen}\left[\frac{360}{365}(\mathrm{DJ}-81)\right]
$$

sendo DJ o dia Juliano.

$\mathrm{O}$ déficit de pressão de vapor $\left(\mathrm{e}_{\mathrm{a}}-\mathrm{e}_{\mathrm{d}}\right)$ foi determinado segundo as equações propostas por Smith (1991):

$$
\begin{aligned}
& e_{s}=0,6108 \exp \left(\frac{17,27 T}{T+237,3}\right) \\
& e_{a}=e_{s} \frac{U R}{100}
\end{aligned}
$$

em que: UR é a umidade relativa do ar, em \%; e e é a pressão de saturação de vapor, em $\mathrm{kPa}$, determinada a partir da padronização sugerida por Sediyama (1996), que toma a média da pressão de saturação de vapor às temperaturas máxima e mínima menos a pressão de vapor de saturação no ponto de orvalho determinada no início da manhã.

A velocidade do vento à $2 \mathrm{~m}$ foi estimada a partir da velocidade do vento a $10 \mathrm{~m}$ utilizando-se a conversão proposta por Smith (1991) para a cobertura padrão:

$$
\mathrm{U}_{2 \mathrm{~m}}=\left\{4,868 \cdot[\ln (67,75 \cdot \mathrm{Z}-5,42)]^{-1}\right\} \cdot \mathrm{U}_{\mathrm{z}}=0,748 \cdot \mathrm{U}_{10 \mathrm{~m}}
$$

em que: $U_{10 \mathrm{~m}}$ é a velocidade média diária do vento $\left(\mathrm{m} \mathrm{s}^{-1}\right)$ na altura $\mathrm{Z}=10 \mathrm{~m}$.

$\mathrm{Na}$ Tabela 5 são apresentados todos os fatores climáticos, necessários para a estimativa da evapotranspiração de referência pelo método de Penman-Monteith. 
Tabela 5. Fatores climáticos médios para os subperíodos considerados

\begin{tabular}{cccccccc}
\hline Subperíodo & $\begin{array}{c}\mathrm{Qg} \\
\mathrm{MJ} \mathrm{m}^{-2} \mathrm{~d}^{-1}\end{array}$ & $\begin{array}{c}\mathrm{T}_{\max } \\
{ }^{\circ} \mathrm{C}\end{array}$ & $\begin{array}{c}\mathrm{T}_{\min } \\
{ }^{\circ} \mathrm{C}\end{array}$ & $\begin{array}{c}\mathrm{n} \\
\mathrm{h} \mathrm{d}^{-1}\end{array}$ & $\begin{array}{c}\mathrm{N} \\
\mathrm{h} \mathrm{d}^{-1}\end{array}$ & $\begin{array}{c}\mathrm{UR} \\
\%\end{array}$ & $\begin{array}{c}\mathrm{U}_{2 \mathrm{~m}} \\
\mathrm{~m} \mathrm{~s}^{-1}\end{array}$ \\
\hline $17-31$ & 13,07 & 24,87 & 9,49 & 6,83 & 10,73 & 79,87 & 1,20 \\
$32-46$ & 8,83 & 22,59 & 11,93 & 4,47 & 10,62 & 87,20 & 1,29 \\
$47-61$ & 11,94 & 25,15 & 11,21 & 6,85 & 10,62 & 79,07 & 1,46 \\
$62-76$ & 11,57 & 26,33 & 11,63 & 6,29 & 10,71 & 76,67 & 1,46 \\
$77-91$ & 13,55 & 26,96 & 11,54 & 7,83 & 10,90 & 75,53 & 1,40 \\
$92-106$ & 14,72 & 26,13 & 9,20 & 7,74 & 11,16 & 67,13 & 1,95 \\
$107-121$ & 17,57 & 31,17 & 12,11 & 9,45 & 11,46 & 55,60 & 1,45 \\
$122-136$ & 14,89 & 28,03 & 14,71 & 5,51 & 11,78 & 74,00 & 1,78 \\
$137-151$ & 20,69 & 28,95 & 13,85 & 9,27 & 12,12 & 67,67 & 2,53 \\
$152-166$ & 17,83 & 28,47 & 15,38 & 6,32 & 12,45 & 74,87 & 1,97 \\
$167-181$ & 20,58 & 28,26 & 14,99 & 7,87 & 12,76 & 72,47 & 2,38 \\
$182-196$ & 17,05 & 27,71 & 15,97 & 4,97 & 13,03 & 76,00 & 2,20 \\
$203-219$ & 21,56 & 31,58 & 18,01 & 7,78 & 13,31 & 72,94 & 1,96 \\
$220-238$ & 21,87 & 30,14 & 18,77 & 7,70 & 13,38 & 77,11 & 1,58 \\
$239-270$ & 19,58 & 30,23 & 19,18 & 6,45 & 13,24 & 82,69 & 1,56 \\
$271-286$ & 16,22 & 29,37 & 19,98 & 4,31 & 12,89 & 87,31 & 1,83 \\
$287-308$ & 21,63 & 30,68 & 18,52 & 7,30 & 12,51 & 84,68 & 1,31 \\
$309-329$ & 15,70 & 29,36 & 18,59 & 4,38 & 12,04 & 84,29 & 1,58 \\
$330-352$ & 18,80 & 29,56 & 15,91 & 8,75 & 11,55 & 75,13 & 1,34 \\
$353-369$ & 16,41 & 28,82 & 13,16 & 7,77 & 11,15 & 73,59 & 1,14 \\
$370-390$ & 14,84 & 25,86 & 10,25 & 7,85 & 10,84 & 71,57 & 1,56 \\
$391-414$ & 12,80 & 26,62 & 10,65 & 6,75 & 10,64 & 73,42 & 1,29 \\
$415-441$ & 13,15 & 25,91 & 10,23 & 6,45 & 10,67 & 68,89 & 1,70 \\
$442-463$ & 13,61 & 25,65 & 9,90 & 6,28 & 10,96 & 70,64 & 1,47 \\
$464-492$ & 13,12 & 25,32 & 12,65 & 5,11 & 11,44 & 71,76 & 1,70 \\
$493-525$ & 18,54 & 29,50 & 16,24 & 6,98 & 12,12 & 70,33 & 1,84 \\
$526-548$ & 20,91 & 32,63 & 18,42 & 7,45 & 12,72 & 67,91 & 1,67 \\
$549-575$ & 19,08 & 29,58 & 17,75 & 6,66 & 13,14 & 78,30 & 1,60 \\
$576-592$ & 18,21 & 29,65 & 18,81 & 5,72 & 13,36 & 79,29 & 1,58 \\
$593-615$ & 20,97 & 30,91 & 19,08 & 7,00 & 13,36 & 78,39 & 1,42 \\
$616-637$ & 20,45 & 31,69 & 19,90 & 6,66 & 13,17 & 77,05 & 1,35 \\
\hline & & & & & & & \\
& & & & & & & \\
& & & &
\end{tabular}




\subsection{Coeficiente de Cultura (Kc)}

$\mathrm{Na}$ determinação do coeficiente de cultura (Kc) considerou-se a evapotranspiração da cultura medida nos lisímetros somada a evapotranspiração das ervas daninhas das entrelinhas. De acordo com Camargo \& Pereira (1990) o Kc é uma função da porcentagem de cobertura do terreno pela folhagem da cultura. Pereira et al (1997) acrescentam que na ocorrência de ervas daninhas, estas também devem ser consideradas, pois também utilizam água do solo. Portanto a evapotranspiração da cultura somada a evapotranspiração das ervas daninhas $(\mathrm{ETcm})$ foi determinada pela equação:

$$
\mathrm{ETcm}=\frac{\mathrm{ETc} \cdot \mathrm{N}}{10000}+\mathrm{p} \cdot \mathrm{Kc}_{\mathrm{m}} \cdot \mathrm{ETo}
$$

em que: ETcm é a evapotranspiração da cultura somada a evapotranspiração das ervas daninhas, em mm d ${ }^{-1}$, ETc é a evapotranspiração da cultura, em L planta ${ }^{-1} \mathrm{~d}^{-1} ; \mathrm{N}$ é o número de plantas $\mathrm{ha}^{-1}$, considerando o espaçamento utilizado; $p=0,643$ é a fração da área livre ocupada pelas plantas daninhas; ETo é a evapotranspiração de referência, em $\mathrm{mm} \mathrm{d}^{-1}$; e $\mathrm{Kc}_{\mathrm{m}}$ é o coeficiente de cultura do mato das entrelinhas. Como o mato das entrelinhas sempre foi mantido roçado, adotou-se o valor de $\mathrm{Kc}_{\mathrm{m}}$ de 0 ,4, sugerido por Doorenbos \& Pruitt (1977) para freqüência de umedecimento de 20 dias, pois somente a precipitação foi responsável pelo umedecimento nesta fração do solo. O mesmo valor foi determinado por Soares (1999) para solos argilosos assim como o da área experimental. O coeficiente de cultura foi determinado pela equação:

$$
\mathrm{Kc}=\frac{\mathrm{ETcm}}{\mathrm{ETo}}
$$

\subsection{Graus dia}

$\mathrm{O}$ acúmulo térmico do maracujazeiro no período estudado foi determinado considerando-se as temperaturas basais mínima $\left(\mathrm{T}_{\mathrm{b}}\right)$ e máxima $\left(\mathrm{T}_{\mathrm{B}}\right)$ de crescimento para 
o maracujazeiro, sendo $8{ }^{\circ} \mathrm{C}$ e $30{ }^{\circ} \mathrm{C}$, respectivamente (Ishihata, 1983; Utsunomiya, 1992; Veras 1997). Durante o desenvolvimento da cultura foram determinadas as necessidades térmicas e a duração de cada uma das fases fenológicas da cultura, proposta por Maciel et al. (1994), que são: fase de crescimento vegetativo inicial, fase de crescimento vegetativo apical, fase de crescimento vegetativo lateral e fase de floração e maturação de frutos. O valor de graus dia (GD) foi calculado, de acordo com Villa Nova et al. (1972):

$$
\begin{aligned}
& \mathrm{GD}=\left(\mathrm{T}_{\mathrm{m}}-\mathrm{T}_{\mathrm{b}}\right)-\mathrm{C} \\
& \mathrm{GD}=\frac{\left(\mathrm{T}_{\max }-\mathrm{T}_{\mathrm{b}}\right)^{2}}{2 \cdot\left(\mathrm{T}_{\max }-\mathrm{T}_{\min }\right)}-\mathrm{C}
\end{aligned}
$$

em que: $\mathrm{T}_{\mathrm{m}}$ é a temperatura média do ar, em ${ }^{\circ} \mathrm{C} ; \mathrm{T}_{\max }$ é a temperatura máxima do ar, em ${ }^{\circ} \mathrm{C}$; $\mathrm{T}_{\min }$ é a temperatura mínima do ar, em ${ }^{\circ} \mathrm{C}$; e $\mathrm{C}$ é a correção para a temperatura base superior.

A equação (23) foi utilizada quando a temperatura mínima do ar esteve maior que $8{ }^{\circ} \mathrm{C}$, que corresponde à temperatura base inferior. Quando $\mathrm{T}_{\min }$ foi menor que $8{ }^{\circ} \mathrm{C}$, a equação (24) foi utilizada. A correção para a temperatura base superior somente foi feita quando a temperatura média do ar esteve acima de $30{ }^{\circ} \mathrm{C}$, que corresponde a temperatura base superior. Esta foi calculada pela equação:

$$
C=\frac{\left(T_{\max }-T_{B}\right)^{2}}{2\left(T_{\max }-T_{\min }\right)}
$$




\section{RESULTADOS E DISCUSSÃO}

Os resultados apresentados na Tabela 6 referem-se aos valores médios dos componentes do balanço hídrico, dentro dos lisímetros, em dois ciclos de produção da cultura do maracujazeiro amarelo no período de 21/05/1999 a 31/01/2001 (17 a 637 DAT). Estes valores são apresentados com base em volume por planta devido à variação da projeção da copa ao longo do ciclo da cultura, que ultrapassa os limites dos lisímetros. Como a evapotranspiração da cultura está diretamente relacionada com o índice de área foliar, verificou-se que ao calcular a lâmina de água evapotranspirada do lisímetro considerando somente a sua área, superdimencionou-se este valor.

$\mathrm{Na}$ Tabela 6, verifica-se que a partir dos 196 DAT a variação de armazenamento de água nos lisímetros tornou-se nula. Isto ocorreu, pois, a partir desta data, os subperíodos foram iniciados após uma drenagem e terminaram no dia em que houve outra drenagem do sistema. Com isso toda a água que entrou no sistema através da irrigação ou da precipitação, saiu pela drenagem ou evapotranspiração. Observa-se, também, que o volume de água que entrou ou saiu no sistema foi variável ao longo dos subperíodos, devido às diferenças no número de dias de cada subperíodo e, principalmente, ao desenvolvimento das plantas.

Como relatado por Alencar (2000) e Sousa (2000) no período compreendido entre 32 e 76 DAT, as plantas, em crescimento inicial, ficaram cobertas com uma cobertura plástica devido à ocorrência de frentes frias. Neste período a temperatura média esteve próxima de $18^{\circ} \mathrm{C}$, que segundo Ruggiero et al. (1996) não se encontra na faixa ideal para o máximo desenvolvimento vegetativo da cultura $\left(21\right.$ e $\left.32{ }^{\circ} \mathrm{C}\right)$. 
Tabela 6. Valores médios dos componentes do balanço hídrico nos lisímetros: Irrigação (I), Precipitação (P), Drenagem (D), Variação do armazenamento $(\Delta \mathrm{S})$ e Evapotranspiração da cultura (ETc)

\begin{tabular}{|c|c|c|c|c|c|}
\hline DAT & $\begin{array}{c}\mathrm{I} \\
\text { L planta }^{-1} \\
\end{array}$ & $\begin{array}{c}\mathrm{P} \\
\text { L planta }^{-1}\end{array}$ & $\begin{array}{c}\mathrm{D} \\
\text { L planta }^{-1}\end{array}$ & $\begin{array}{c}\Delta \mathrm{S} \\
\text { L } \text { planta }^{-1}\end{array}$ & $\begin{array}{c}\text { ETc } \\
\text { L planta }^{-1} \mathrm{~d}^{-1}\end{array}$ \\
\hline $17-31$ & 88,83 & 8,59 & 72,88 & 9,08 & 1,03 \\
\hline $32-46$ & 29,45 & 0,00 & 20,37 & 0,67 & 0,56 \\
\hline $47-61$ & 36,69 & 0,00 & 22,58 & $-0,43$ & 0,97 \\
\hline $62-76$ & 26,99 & 0,00 & 20,74 & $-0,92$ & 0,48 \\
\hline $77-91$ & 35,58 & 0,00 & 28,71 & $-2,70$ & 0,64 \\
\hline $92-106$ & 69,33 & 0,00 & 32,64 & 9,26 & 1,83 \\
\hline $107-121$ & 93,62 & 0,00 & 51,66 & $-6,26$ & 3,21 \\
\hline $122-136$ & 53,87 & 139,88 & 118,04 & 6,87 & 4,59 \\
\hline $137-151$ & 75,58 & 0,00 & 4,54 & 0,55 & 4,70 \\
\hline $152-166$ & 55,58 & 38,04 & 12,27 & 9,20 & 4,81 \\
\hline $167-181$ & 56,56 & 14,11 & 6,50 & $-16,99$ & 5,15 \\
\hline $182-196$ & 77,55 & 41,10 & 15,58 & 16,93 & 5,66 \\
\hline $203-219$ & 75,72 & 130,80 & 27,00 & 0,00 & 10,56 \\
\hline $220-238$ & 39,67 & 213,62 & 34,60 & 0,00 & 11,51 \\
\hline $239-270$ & 241,81 & 281,11 & 29,80 & 0,00 & 15,41 \\
\hline $271-286$ & 348,51 & 141,72 & 30,13 & 0,00 & 18,93 \\
\hline $287-308$ & 493,40 & 49,10 & 54,42 & $-5,01$ & 23,37 \\
\hline $309-329$ & 485,08 & 65,99 & 67,87 & 5,01 & 22,81 \\
\hline $330-352$ & 451,27 & 1,43 & 51,04 & 0,00 & 22,20 \\
\hline $353-369$ & 385,03 & 5,58 & 41,90 & 0,00 & 21,95 \\
\hline $370-390$ & 362,88 & 0,00 & 29,29 & 0,00 & 16,65 \\
\hline $391-414$ & 394,24 & 5,72 & 10,42 & 0,00 & 13,96 \\
\hline $415-441$ & 341,79 & 53,39 & 38,93 & 0,00 & 14,52 \\
\hline $442-463$ & 305,48 & 7,57 & 17,91 & 0,00 & 14,12 \\
\hline $464-492$ & 475,59 & 122,16 & 44,61 & 0,00 & 14,34 \\
\hline $493-525$ & 481,15 & 54,16 & 28,40 & 0,00 & 19,82 \\
\hline $526-548$ & 284,38 & 81,45 & 48,01 & 0,00 & 16,03 \\
\hline $549-575$ & 261,83 & 240,09 & 25,83 & 0,00 & 16,26 \\
\hline $576-592$ & 355,40 & 64,68 & 25,82 & 0,00 & 19,77 \\
\hline $593-615$ & 396,16 & 151,42 & 25,40 & 0,00 & 23,22 \\
\hline $616-637$ & 388,98 & 178,99 & 65,75 & 0,00 & 25,23 \\
\hline Total & 7268,02 & 2090,70 & 1103,62 & 25,28 & - \\
\hline
\end{tabular}


Além disso, a radiação solar apresentou-se em torno de $10,8 \mathrm{MJ} \mathrm{m}^{-2} \mathrm{~d}^{-1}$, sendo baixa para o desenvolvimento vegetativo da cultura (Menzel \& Simpson, 1988). Conforme relatado por Matzenouer et al. (1998), decréscimo no valor de radiação solar, que é a fonte de energia utilizada no processo de evapotranspiração, provoca redução na demanda evaporativa. Observa-se que a partir deste período, com o aumento da disponibilidade de energia e o desenvolvimento das plantas o consumo hídrico da cultura aumentou de forma contínua até 308 DAT, estabilizando-se por 83 dias com consumo hídrico médio de 22,8 $\mathrm{L}_{\text {planta }}{ }^{-1} \mathrm{~d}^{-1}$, durante a época de máximo florescimento e frutificação. No período de 370 a 492 DAT, a ETc diminuiu para um valor médio de 14,7 $\mathrm{L}_{\text {planta }} \mathrm{d}^{-1}$, em decorrência da redução da temperatura para um valor médio 18,3 ${ }^{\circ} \mathrm{C}$ e redução da radiação solar para $13,5 \mathrm{MJ} \mathrm{m}^{-2} \mathrm{~d}^{-1}$ (Tabela 5), além do final do período de produção, já que o fotoperíodo reduziu para um valor próximo de 10 horas de luz.

A partir de 493 DAT a ETc volta a aumentar devido à elevação da temperatura e da radiação solar, atingindo $19,82 \mathrm{~L}_{\text {planta }} \mathrm{d}^{-1}$. A queda verificada nos dois subperíodos seqüentes (526 a 575 DAT), é explicada pela realização da poda de limpeza e renovação do pomar realizada no período de 525 a 533 DAT. Entretanto, como as plantas não sofreram déficit hídrico, a temperatura e a radiação solar estiveram altas neste período, e as plantas foram fertilizadas semanalmente (Tabela 5), o desenvolvimento vegetativo foi rápido atingindo o valor de $25,3 \mathrm{~L}_{\text {planta }} \mathrm{d}^{-1}$ no período de 616 a $637 \mathrm{DAT}$, que correspondeu ao florescimento e frutificação do segundo ciclo produtivo.

$\mathrm{O}$ volume médio de água evapotranspirada pela cultura do maracujazeiro ao final do primeiro ciclo de produção (17 a 463 DAT) foi de $5000 \mathrm{~L} \mathrm{planta}^{-1}$. Durante os dois ciclos de produção o consumo foi de $8280 \mathrm{~L}_{\text {planta }}{ }^{-1}$. Na literatura, não se encontram informações sobre a necessidade hídrica com base em volume para a cultura do maracujazeiro, entretanto em cacaueiros adultos Almeida et al. (1999) utilizando-se do método do balanço hídrico encontraram um consumo de $20,2 \mathrm{~L}_{\text {planta }}{ }^{-1}$, que se aproxima ao verificado neste experimento.

Com base dos valores de consumo hídrico da cultura, em volume, da projeção da copa, da evapotranspiração de referência e considerando um Kc de 0,4 para as plantas daninhas da entrelinha (Doorenbos \& Pruitt, 1977; Soares, 1999), determinou-se a 
evapotranspiração da cultura considerando a área do espaçamento (ETcm), conforme Tabela 7. Observa-se que em todos os subperíodos a ETcm nos lisímetros apresentou valores muito próximos com um coeficiente de variação máximo de $10 \%$, comprovando que as 4 plantas tiveram desenvolvimento vegetativo e produtivo muito semelhantes. As pequenas variações observadas podem estar associadas à variabilidade espacial das propriedades físicas do solo, tais como grau de compactação nas camadas, permeabilidade, velocidade de infiltração e capacidade de retenção de água.

A ETcm da cultura para o primeiro ciclo de produção foi de $750 \mathrm{~mm}$, diferindo do valor encontrado por Silva (2001) em Botucatu, SP, que foi de $955 \mathrm{~mm}$. Esta diferença pode ser atribuída às diferentes épocas de plantio, pois como Silva (2001) transplantou as mudas no mês de setembro, o crescimento vegetativo da cultura foi máximo, devido à elevadas temperaturas, alcançando o período produtivo em menor tempo. Além disso, pode-se considerar que a metodologia utilizada por Silva (2001) para o cálculo da lâmina evapotranspirada pode ocasionar diferenças entre os valores.

Os maiores valores de ETcm encontrados nos lisímetros ocorreram no período de floração, formação e maturação dos frutos, sendo de $3,01 \mathrm{~mm} \mathrm{~d}^{-1}$ no primeiro ciclo e $3,37 \mathrm{~mm} \mathrm{~d}^{-1}$ no segundo ciclo produtivo. Estes valores se aproximaram do encontrado por Silva (2001) para o mesmo período do primeiro ciclo produtivo $\left(3,21 \mathrm{~mm} \mathrm{~d}^{-1}\right)$, indicando que a metodologia utilizada no cálculo da ETcm apresentou-se viável.

$\mathrm{O}$ coeficiente de cultura $(\mathrm{Kc})$ foi determinado a partir da ETcm média dos 4 lisímetros e da ETo estimada pelo método de Penman Monteith. O Kc é um índice determinado a partir da relação entre a evapotranspiração da cultura $(E T c)$ e a evapotranspiração de referência (ETo) e serve para medir os efeitos das características da cultura sobre as necessidades hídricas (Doorembos \& Pruitt, 1977). Os valores de Kc determinados para o maracujazeiro amarelo estão apresentados na Tabela 7.

Normalmente, os valores de coeficientes de cultivo aumentam, atingem um máximo, e depois diminuem em função do ciclo da planta. Na fase inicial que compreende a germinação e o início do crescimento vegetativo, ou transplantio de mudas, pegamento e crescimento inicial, quando se tratar de fruteiras, a área de solo 
coberta pela planta é muito pequena, o que resulta em pequeno consumo de água sendo os valores de Kc baixos.

Tabela 7. Valores de evapotranspiração da cultura somada a evapotranspiração das plantas daninhas (ETcm), evapotranspiração de referência (ETo) e coeficiente de cultura $(\mathrm{Kc})$

\begin{tabular}{|c|c|c|c|c|c|c|c|c|}
\hline \multicolumn{7}{|c|}{ ETcm do maracujazeiro } & ETo & \multirow[t]{2}{*}{$\mathrm{Kc}$} \\
\hline DAT & L 1 & L 2 & $\begin{array}{l}\mathrm{L} 3 \\
\mathrm{~mm} \mathrm{~d}^{-1}\end{array}$ & L 4 & Média & $\begin{array}{c}\text { CV } \\
\%\end{array}$ & $\mathrm{~mm} \mathrm{~d}^{-1}$ & \\
\hline $17-31$ & 0,55 & 0,55 & 0,56 & 0,55 & 0,55 & 0,54 & 1,64 & 0,34 \\
\hline $32-46$ & 0,39 & 0,40 & 0,38 & 0,38 & 0,38 & 2,37 & 1,18 & 0,33 \\
\hline $47-61$ & 0,53 & 0,53 & 0,53 & 0,53 & 0,53 & 0,26 & 1,58 & 0,34 \\
\hline $62-76$ & 0,55 & 0,56 & 0,55 & 0,54 & 0,55 & 1,77 & 1,76 & 0,31 \\
\hline $77-91$ & 0,60 & 0,59 & 0,60 & 0,60 & 0,60 & 0,40 & 1,88 & 0,32 \\
\hline $92-106$ & 0,83 & 0,82 & 0,84 & 0,83 & 0,83 & 1,12 & 2,40 & 0,35 \\
\hline $107-121$ & 1,12 & 1,10 & 1,13 & 1,16 & 1,13 & 2,33 & 3,07 & 0,37 \\
\hline $122-136$ & 1,16 & 1,09 & 1,16 & 1,17 & 1,15 & 3,34 & 2,80 & 0,41 \\
\hline $137-151$ & 1,48 & 1,42 & 1,48 & 1,49 & 1,47 & 2,01 & 3,87 & 0,38 \\
\hline $152-166$ & 1,36 & 1,33 & 1,36 & 1,38 & 1,36 & 1,55 & 3,46 & 0,39 \\
\hline $167-181$ & 1,60 & 1,56 & 1,59 & 1,53 & 1,57 & 2,03 & 3,99 & 0,39 \\
\hline $182-196$ & 1,45 & 1,49 & 1,48 & 1,47 & 1,47 & 1,12 & 3,55 & 0,42 \\
\hline $203-219$ & 1,99 & 2,09 & 2,16 & 2,22 & 2,12 & 4,68 & 4,52 & 0,47 \\
\hline $220-238$ & 2,21 & 2,22 & 2,16 & 2,23 & 2,20 & 1,32 & 4,25 & 0,52 \\
\hline $239-270$ & 2,35 & 2,29 & 2,45 & 2,35 & 2,36 & 2,71 & 3,87 & 0,61 \\
\hline $271-286$ & 2,37 & 2,26 & - & 2,70 & 2,44 & 9,34 & 3,36 & 0,73 \\
\hline $287-308$ & 3,01 & 2,81 & - & 3,21 & 3,01 & 6,66 & 4,13 & 0,73 \\
\hline $309-329$ & 2,83 & 2,92 & - & 2,61 & 2,79 & 5,76 & 3,14 & 0,89 \\
\hline $330-352$ & 2,76 & 2,68 & - & 2,75 & 2,73 & 1,57 & 3,10 & 0,88 \\
\hline $353-369$ & 2,54 & 2,46 & - & 2,53 & 2,51 & 1,74 & 2,55 & 0,98 \\
\hline $370-390$ & 1,83 & 1,94 & - & 2,20 & 1,99 & 9,48 & 2,17 & 0,92 \\
\hline $391-414$ & 1,53 & 1,71 & - & 1,82 & 1,69 & 8,83 & 1,87 & 0,90 \\
\hline $415-441$ & 1,81 & 1,80 & - & 1,99 & 1,87 & 5,68 & 2,24 & 0,83 \\
\hline $442-463$ & 1,69 & 1,84 & - & 1,89 & 1,81 & 5,78 & 2,16 & 0,84 \\
\hline $464-492$ & 1,78 & 1,84 & 2,05 & 2,04 & 1,93 & 7,13 & 2,45 & 0,79 \\
\hline $493-525$ & 2,48 & 2,74 & 2,91 & 2,94 & 2,77 & 7,65 & 3,66 & 0,76 \\
\hline $526-548$ & 2,68 & 2,90 & 2,74 & 2,89 & 2,81 & 3,92 & 4,50 & 0,62 \\
\hline $549-575$ & 2,46 & 2,64 & 2,52 & 2,61 & 2,56 & 3,37 & 3,78 & 0,68 \\
\hline $576-592$ & 2,75 & 2,78 & 2,77 & 2,74 & 2,76 & 0,67 & 3,66 & 0,76 \\
\hline $593-615$ & 3,20 & 3,27 & 3,30 & 3,10 & 3,22 & 2,76 & 4,22 & 0,76 \\
\hline $616-637$ & 3,35 & 3,37 & 3,35 & 3,42 & 3,37 & 1,02 & 4,24 & 0,80 \\
\hline
\end{tabular}


Já na fase de pleno desenvolvimento, a demanda hídrica da cultura aumenta e o Kc tende a atingir valores máximos (Doorembos \& Pruitt, 1977; Doorembos \& Kassam, 1979; Marouelli et al., 1994; Pereira et al., 1997). Essa tendência foi observada para o maracujazeiro, com valores variando de 0,34 no período inicial de desenvolvimento a 0,98 no período de florescimento e frutificação do primeiro ciclo produtivo.

Como visto anteriormente, a determinação da evapotranspiração da cultura considerando a área do espaçamento $(\mathrm{ETcm})$ foi calculada considerando a evapotranspiração da cultura do maracujazeiro e a evapotranspiração das plantas daninhas da entrelinha. A Figura 7a ilustra como foi o comportamento da cultura e do mato da entrelinha no somatório da ETcm. Nota-se que no início a evapotranspiração do mato da entrelinha correspondeu à $90 \%$ da ETcm, concluindo que a irrigação no período inicial da cultura do maracujazeiro, em área total, deve atender não somente a cultura, mas também as ervas daninhas ou a evaporação do solo nú. A partir de 250 DAT, a participação da evapotranspiração do maracujazeiro passa a ser mais representativa na ETcm, principalmente, no período de produção da cultura. Entretanto, observa-se que mesmo no período de produção a participação das ervas daninhas corresponde a $40 \%$ da ETcm.

A Figura $7 \mathrm{~b}$ ilustra o comportamento da ETcm e da ETo durante os dois ciclos produtivos da cultura. Observa-se que enquanto o maracujazeiro amarelo se encontra em desenvolvimento inicial, a diferença entre ETo e ETcm é relativamente grande, pois a cultura de referência encontra-se em pleno desenvolvimento e com índice de área foliar máximo. Entretanto, esta diferença diminui com o aumento da massa foliar do maracujazeiro, principalmente no período de produção. Além disso, o comportamento da ETcm, segue o mesmo comportamento da ETo ao longo do ano. Observa-se que o ciclo da cultura foi dividido em 6 estádios de desenvolvimento, de acordo com Maciel et al. (1994), em que:

Estádio I - Crescimento vegetativo inicial ou fase juvenil;

Estádio II - Crescimento vegetativo apical;

Estádio III - Crescimento vegetativo lateral; 
Estádio IV - Floração, frutificação e maturação dos frutos no primeiro ano de produção;

Estádio V - Repouso vegetativo;

Estádio VI - Floração e frutificação do segundo ano de produção.

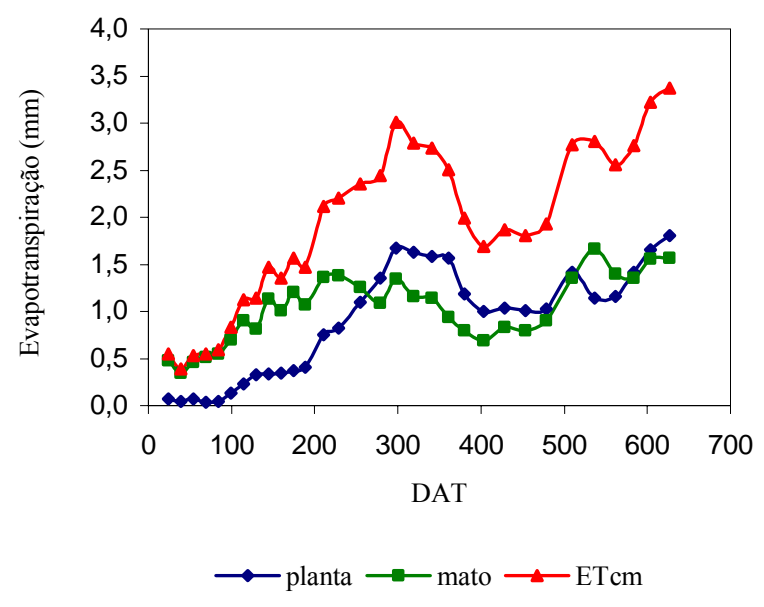

(a)

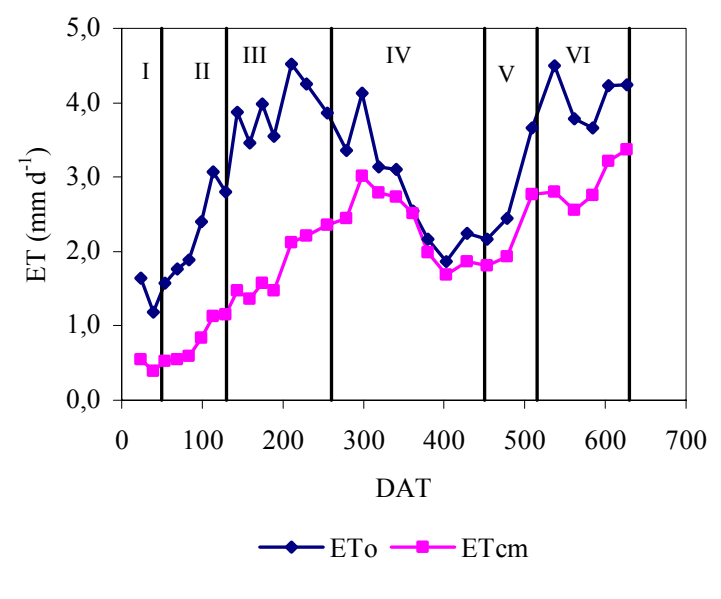

(b)

Figura 7 - Partição da evapotranspiração do maracujazeiro e das plantas daninhas (a); evapotranspiração da cultura e evapotranspiração de referência ao longo dos estádios fenológicos da cultura do maracujazeiro (b)

Em cada estádio de desenvolvimento, determinou-se o acúmulo térmico do período, através da metodologia descrita em Villa Nova et al. (1972), considerando as temperaturas basais mínima e máxima de 8 e $30{ }^{\circ} \mathrm{C}$, respectivamente. Observa-se na Figura 8a, que em algumas épocas do ano, a temperatura basal máxima foi superada, necessitando utilizar o fator de correção proposto por Villa Nova et al. (1972), pois nestas condições a planta não se desenvolve, ou se desenvolve em taxas bem reduzidas. Da mesma forma, no período do inverno houve dias em que a temperatura mínima do ar esteve abaixo da temperatura basal inferior, não havendo desenvolvimento vegetativo da cultura nestas condições. A Figura $8 \mathrm{~b}$ ilustra o acumulo total de energia em graus dia durante os dois ciclos de produção, totalizando 8748 graus-dia. No primeiro ciclo de 
produção o somatório térmico foi de 5880 graus-dia, estando próximo do verificado por Melo (2001) no primeiro ano de produção da cultura (6545 graus-dia).

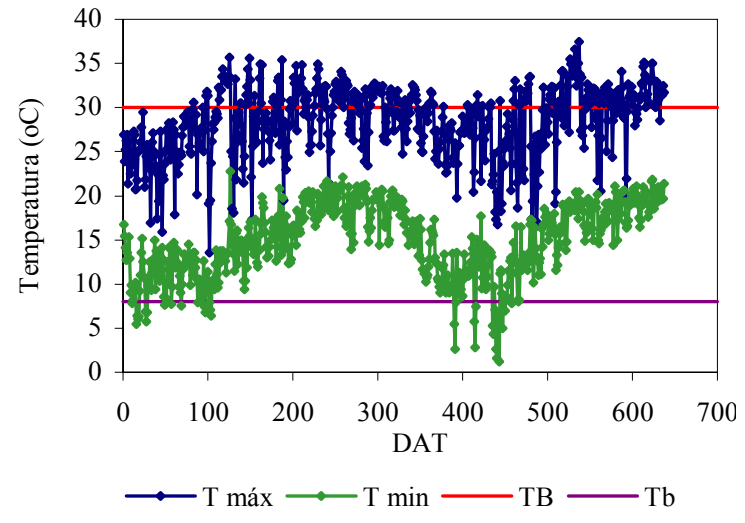

(a)

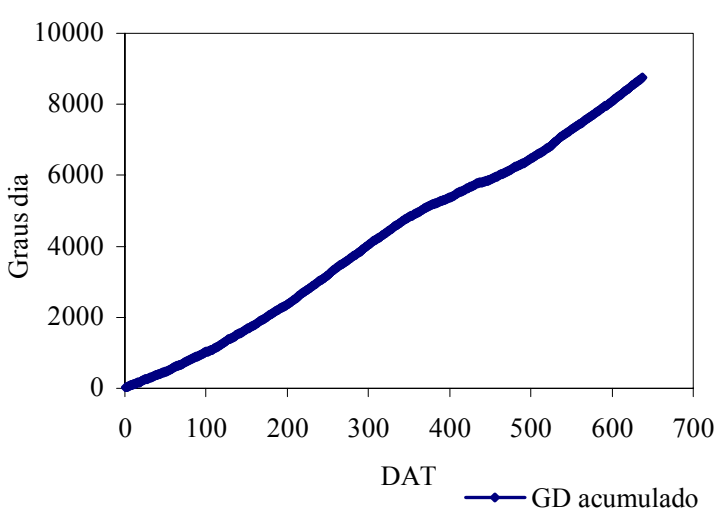

(b)

Figura 8 - Temperaturas máxima e mínima nos dois ciclos produtivos do maracujazeiro amarelo (a); Graus dia acumulado em todo o período de produção (b)

A Tabela 8 apresenta cada estádio de desenvolvimento do maracujazeiro, com suas respectivas características. Nos primeiros 50 dias de desenvolvimento, a planta se encontrou no período caracterizado de juvenil, onde a cultura apresenta apenas uma haste cilíndrica com entrenós curtos e folhas simples. Neste período a cultura acumulou 470,2 graus-dia, apresentando projeção da copa de aproximadamente $0,06 \mathrm{~m}^{2}$ e Kc de 0,4. Melo (2001) verificou que nas condições de Visconde do Rio Branco, MG, a necessidade térmica para o mesmo período foi de 575 graus-dia em um período de 30 dias e Kc de 0,3. Este mesmo valor de Kc foi determinado por Silva (2001) e utilizado por Martins (1998). Entretanto, como o transplantio das mudas no campo foi seguido de um período de baixas temperaturas e radiação solar, a evapotranspiração da cultura foi reduzida e consequentemente o Kc foi menor.

Após o término da fase de crescimento inicial, deu-se início à fase de crescimento vegetativo apical com a continuação do desenvolvimento do ramo principal até ultrapassar o fio de tutoramento, atingindo $2 \mathrm{~m}$ de altura. Esta fase é considerada como de transição, onde ocorrem mudanças fisiológicas e morfológicas com o aumento 
do comprimento dos entrenós, mudança na forma das folhas e presença de gavinhas (Maciel et al., 1994). Neste período, a necessidade térmica (931,21 graus-dia) foi muito próxima ao valor verificado por Melo (2001) que foi de 925 graus-dia. Entretanto o Kc médio manteve-se em torno de 0,4 , em decorrência do atraso do crescimento vegetativo da cultura, ocasionado pelas frentes frias, estando abaixo do Kc utilizado por Melo (2001) que foi de 0,6. Neste período a projeção da copa foi de $0,09 \mathrm{~m}^{2}$.

Tabela 8 - Características fenológicas nos estádios de desenvolvimento do maracujazeiro amarelo

\begin{tabular}{cccccccc}
\hline $\begin{array}{c}\text { Período } \\
(\mathrm{DAT})\end{array}$ & $\begin{array}{c}\text { Estádio } \\
\text { Fenológico }\end{array}$ & $\begin{array}{c}\text { Projeção } \\
\text { da copa } \\
\left(\mathrm{m}^{2}\right)\end{array}$ & $\mathrm{n}$ & $\begin{array}{c}\text { ETcm } \\
(\mathrm{mm})\end{array}$ & $\begin{array}{c}\text { GD } \\
\text { acumulado } \\
\text { no período }\end{array}$ & $\begin{array}{c}\text { GD } \\
\text { acumulado } \\
\text { total }\end{array}$ & Kc \\
\hline $1-50$ & Fase juvenil & 0,06 & 50 & 17,2 & 470,20 & 470,20 & 0,3 \\
$51-130$ & Transição 1 & 0,09 & 80 & 50,7 & 931,21 & 1401,41 & 0,4 \\
$131-260$ & Transição 2 & 1,40 & 130 & 202,4 & 1976,29 & 3377,70 & 0,5 \\
$261-450$ & Adulta 1 & 3,70 & 190 & 378,9 & 2502,34 & 5880,04 & 0,9 \\
$451-515$ & Repouso & 4,00 & 65 & 129,5 & 800,45 & 6680,49 & 0,8 \\
$516-637$ & Adulta 2 & 4,00 & 122 & 286,5 & 2067,49 & 8747,98 & 0,7 \\
\hline
\end{tabular}

O terceiro estádio de desenvolvimento da cultura, denominado de crescimento vegetativo lateral, é caracterizado com o crescimento de dois ramos laterais, conduzidos um para cada lado da planta, até atingirem $2 \mathrm{~m}$ de comprimento, pois o espaçamento entre plantas foi de $4 \mathrm{~m}$. Nesta fase, a cultura ainda apresentou características de fase de transição, com o aparecimento das primeiras folhas trilobadas (Maciel et al., 1994). Nesta fase surgiram as primeiras flores em decorrência de fotoperíodos acima de $12 \mathrm{~h}$ de luz. Entretanto, como as plantas ainda não se encontravam em estádio avançado de desenvolvimento, considerou-se o início do florescimento como pertencente à fase de transição, pois o crescimento vegetativo ocorria de forma muito rápida. Este período durou cerca de 130 dias, necessitando de 1976 graus-dia com um aumento da projeção da copa para 1,40 $\mathrm{m}^{2}$ e um Kc médio de 0,5.

Após o crescimento vegetativo lateral, caracterizou-se a fase de florescimento, frutificação e maturação dos frutos que durou cerca de 190 dias exigindo 2500 graus-dia 
e um Kc médio de 0,9. Melo (2001) verificou uma exigência de 4050 graus-dia em 240 dias, utilizando um valor de Kc igual a 0,8. A diferença na exigência térmica é justificada pelo período considerado como de florescimento e frutificação nos dois experimentos.

O quinto estádio de desenvolvimento corresponde ao período onde a planta entrou em repouso vegetativo, em decorrência da redução da temperatura e da radiação solar. Neste período, as plantas ainda apresentavam massa vegetativa muito intensa, ocasionando em elevados valores de ETcm e conseqüentemente uma pequena redução no valor do Kc $(0,8)$, num período de 65 dias acumulando 800 graus-dia. Neste período realizou-se a poda de limpeza e renovação do pomar, reduzindo a ETcm. Com isso no sexto estádio de desenvolvimento, que corresponde novamente ao florescimento e frutificação do maracujazeiro, observou-se a queda do valor de Kc para 0,7. Entretanto, como o período produtivo do segundo ciclo de produção, provavelmente se estenderia por mais 120 dias, o desenvolvimento vegetativo seria máximo e o Kc seria igual ao do primeiro ciclo de produção.

A Figura 9 ilustra os valores médios do coeficiente de cultura ao longo dos estádios fenológicos do maracujazeiro. Observou-se que o comportamento da curva verificado neste experimento assemelhou-se à curva apresentada por Silva (2001), com algumas diferenças nos valores. Entretanto, é necessário cuidado, pois dentro da mesma espécie ou variedade podem ocorrer diferenças nos valores entre regiões distintas, bem como a metodologia utilizada na determinação da ETo e da ETc. Isto foi evidenciado nos trabalhos de Netto et al. (1997) e Teixeira et al. (1999), que encontraram valores que variaram de 0,55 a 0,65 e 0,56 a 1,15, respectivamente, para a mesma variedade de videira na região de Petrolina, $\mathrm{PE}$. 


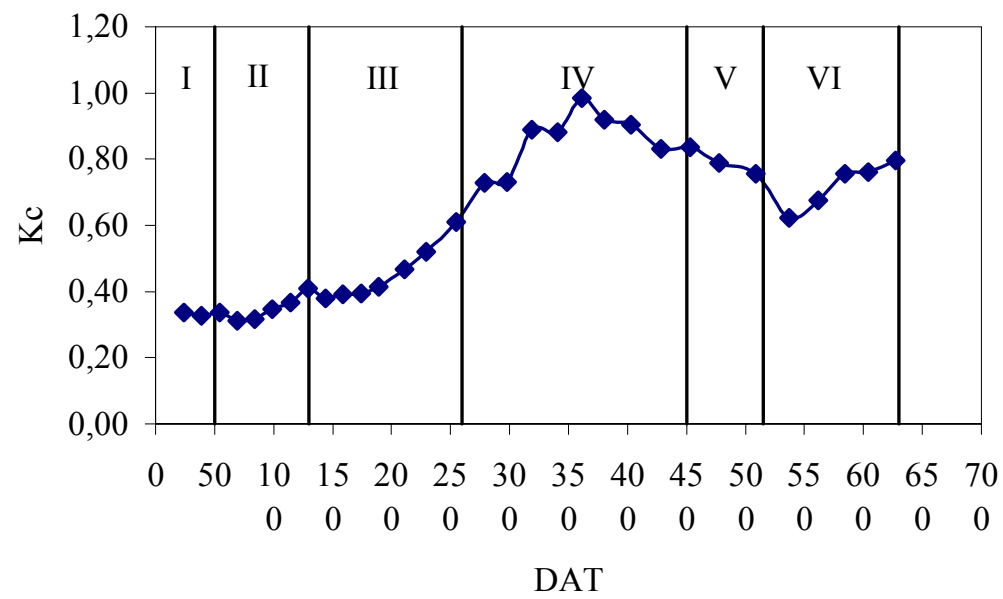

Figura 9 - Valores de Kc ao longo de dois ciclos de produção do maracujazeiro amarelo 


\section{CONCLUSÕES}

Os resultados obtidos neste trabalho permitiram as seguintes conclusões:

a) Após 76 dias do transplantio das mudas os valores médios de evapotranspiração da cultura foram crescentes, atingindo o valor máximo de $23,37 \mathrm{~L}_{\text {planta }}{ }^{-1} \mathrm{dia}^{-1}$ no período compreendido entre 287 e 308 dias após o mesmo (floração e frutificação). Considerando a área total do espaçamento, com ervas daninhas ocupando as entrelinhas, este valor foi de aproximadamente $3,01 \mathrm{~mm} \mathrm{~d}^{-1}$.

b) Em condições de irrigação na área total, a evapotranspiração das plantas daninhas das entrelinhas deve ser considerada, pois pode corresponder a até $90 \%$ da evapotranspiração total da área.

c) O consumo hídrico total no primeiro ciclo de produção foi de 750,76 mm em 447 dias, com acúmulo térmico de 5880 graus-dia.

d) Os valores médios de Kc aumentaram de 0,31 a 0,98 seguindo o aumento da área foliar, observada em função da projeção da copa que atingiu valor máximo de $4 \mathrm{~m}^{2}$.

e) Durante o ciclo do maracujazeiro foram determinados 6 estádios de desenvolvimento, com valores de Kc de 0,3 para a fase de desenvolvimento inicial, 0,4 para a fase de crescimento vegetativo apical, 0,5 para a fase de crescimento vegetativo lateral, 0,9 para a fase de florescimento, frutificação e maturação dos frutos, 0,8 para a fase de repouso vegetativo e 0,7 para o início do florescimento e frutificação do segundo ciclo de produção. 


\section{REFERÊNCIAS BIBLIOGRÁFICAS}

ABOUKHAlED, A.; ALFARO, A.; SMITH, M. Lisimeters. Rome: FAO, 1982. 68p.(FAO. Irrigation and Drainage Paper, 39).

ALENCAR, C.M. de. Consumo de água do maracujazeiro amarelo (Passiflora edulis Sims. f. flavicarpa Deg.). Piracicaba, 2000. 49p. Dissertação (Mestrado) - Escola Superior de Agricultura "Luiz de Queiroz”, Universidade de São Paulo.

ALLEN, R.G.; JENSEN, M.E.; WRIGHT, J. BURMAN, R.D. Operational estimates of reference evapotranspiration. Agronomy Journal, v.81, p.650-662, 1989.

ALMEIDA, H.A. de; MACHADO, R.C.R.; VILLA NOVA, N.A.; KLAR, A.E. Estimativa do consumo de água em cacaueiros adultos. In: CONGRESSO BRASILEIRO DE AGROMETEOROLOGIA, Florianópolis, 1999. Anais. Florianópolis: SBA, 1999. v.1, p. 428.

ASSIS, F.N. O uso do evapotranspirômetro no estudo de algumas relações entre a evapotranspiração medida e estimada. Piracicaba, 1978. 73p. Dissertação (Mestrado) - Escola Superior de Agricultura “Luiz de Queiroz”, Universidade de São Paulo.

BURMAN, R.D.; NIXON, P.R.; WRIGHT, J.L.; PRUITT, W.O. Water requirements. In: JJENSEN, M.E. Design and operation of farm irrigation systems. St. Joseph: ASAE, 1980. cap. 6, p.189-232. 
CAMARGO, A.P. Contribuição para a determinação da evapotranspiração potencial no Estado de São Paulo. Bragantia, v.21, n.12, p.163-213, 1962.

CAMARGO, A.P. Balanço hídrico no Estado de São Paulo. Campinas: IAC, 1971. 29p. (Boletim Técnico, 116).

CAMARGO, M.E. Exigências bioclimáticas e estimativa da produtividade para quatro cultivares de soja no Estado de São Paulo. Piracicaba, 1984. 96p. Dissertação (Mestrado) - Escola Superior de Agricultura "Luiz de Queiroz", Universidade de São Paulo.

CAMARGO, A.P.; PEREIRA, A.R. Prescrição de rega por modelo climatológico. Campinas: Fundação Cargill, 1990. 27p.

COELHO, E.F. Irrigação. In: LIMA, A.A. (Coord.) O cultivo do maracujá. Cruz das Almas: Embrapa Mandioca e Fruticultura, 1999. p. 48-54 (Circular Técnica, 35).

DOORENBOS, J.; PRUITT, J.O Guidelines for predicting crop water requeriments. Rome: FAO, 1977. 179p. (Irrigation and Drainage Paper, 24).

DOORENBOS, J.; KASSAM, A.H. Efectos del agua sobre el rendimento de los cultivos. Roma: FAO, 1979. 212p. (Riego y drenage, 33).

FIGUEIREDO, R.W.; SESSA, M.C.M.; HOLANDA, L.F.F. et al. Estudos das características físicas e do rendimento do maracujá amarelo. In: CONGRESSO BRASILEIRO DE FRUTICULTURA, 9., Campinas, 1987. Anais. Campinas: Sociedade Brasileira de Fruticultura, 1988. v. 2. p.613-617.

FNP Consultoria \& Comércio Agrianual 2003: anuário estatístico da agricultura brasileira. São Paulo, 2003. p.399-405: Maracujá. 
HAAG, H. P.; OLIVEIRA, G.D; BOURDUCHI, A. S.; SARRUGE, J. R. Absorção de nutrientes por duas variedades de maracujá. ESALQ/USP. Anais da Escola Superior de Agricultura "Luiz de Queiroz” Universidade de São Paulo, v. 30, p. 267-279, 1973.

HOEHNE, F.C. Frutas indígenas. São Paulo: Instituto de Botânica, 1946. p. 62-65.

ISHIHATA, K. On the pollen germination of purple passionfruit, Passiflora edulis Sims. Bulletin Faculty of Agriculture Kagoshima University, v. 33, p.7-12, 1983.

KLIEMANN, H. J; CAMPELO JÚNIOR, J. H; AZEVEDO, J. A; GUILHERME, M. R; GENÚ, P. J. C. Nutrição mineral e adubação do maracujazeiro. In: H.P. HAAG. Nutrição Mineral e adubação de fruteiras tropicais. Campinas: Fundação Cargill, 1986. p.247-284.

LUCAS, A.A.T. Resposta do maracujazeiro amarelo (Passiflora edulis Sins var. flavicarpa Deg) a lâminas de irrigação e doses de adubação potássica. Piracicaba, 2002. 88p. Dissertação (Mestrado) - Escola Superior de Agricultura "Luiz de Queiroz", Universidade de São Paulo.

MACIEL, N.; BATUTISTA, D.; AULAR, J. Crescimiento, desarrolo y arquitectura de Passiflora edulis f. flavicarpa. Proceeding Interamerican Society Tropical Horticultural, n. 38, p. 133-38, 1994.

MANICA, I. Fruticultura tropical: Maracujá. São Paulo: Ed. Agronômica Ceres, 1981. $151 \mathrm{p}$.

MAROUELli, A. W.; SILVA, W. L. C.; SILVA, H. R. Manejo da irrigação em hortaliças. Brasília: Empresa Brasileira de Pesquisa Agropecuária, Centro Nacional de Pesquisa de Hortaliças. EMBRAPA-SPI, 1994. 60p. 
MARTINS, D.P. Resposta do maracujazeiro amarelo (Passiflora edulis Sims. f. flavicarpa Deg.) a lâminas de irrigação e doses de nitrogênio e potássio. Campos dos Goytacazes, 1998. 84p. Tese (Doutorado) - Centro de Ciências e Tecnologias, Universidade Estadual do Norte Fluminense.

MATZENOUER, R; BERGAMASCHI, H; BERLATO, M. A. Evapotranspiração da cultura do milho II- relação com evaporação do tanque classe A, com evaporação de referência e com a radiação solar global em três época de semeadura. Revista Brasileira de Agrometeorologia. v.6, n.1, p.15-20, 1998.

MEDINA, J.C.; GARCIA, J.L.M.; LARA, L.C.C.; TOCHINI, R.P.; HASHIZUME, T.; MORETTI, V.A.; CANTO, W.L. Maracujá: da cultura ao processamento e comercialização. Campinas: Secretaria da Agricultura e Abastecimento, ITAL, 1980. $207 \mathrm{p}$.

MELETTI, L. M. M.; MAIA, M. L. Maracujá: produção e comercialização. Campinas: Instituto Agronômico de Campinas, 1999. 64p. (Boletim técnico, 181).

MELO, M.A.N. Determinação da necessidade térmica, adequação de coeficiente da cultura e efeito da irrigação e da adubação nitrogenada na produção do maracujazeiro amarelo. Viçosa, 2001. 138 p. Dissertação (M.S.), Universidade Federal de Viçosa.

MENZEL, C.M; SIMPSON, D.R.; DOWLING, A.J. Water relations in passion fruit: effect of moisture stress on growth, flowering and nutrient uptake. Scientia Horticulturae, v.29, p.239-249, 1986.

MENZEL, C.M; SIMPSON, D.R.; WINKS, C.M. Effect of temperature on growth, flowering and nutrient uptake of three passion fruit cultivars under low irradiance. Scientia Horticulturae, v. 31, n. 3/4, p. 259-268, 1987. 
MENZEL, C.M; SIMPSON, D.R. Effect of continuous shading on growth, flowering and nutrient uptake of passionfruit. Scientia Horticulturae, v. 35, p. 77-88, 1988.

MILlO, J.L.; CUNHA, J.B. Manual do sistema de irrigação xiquexique. Recife: Superintendência do desenvolvimento do Nordeste, 1982. 109p.

MONTEITH, J.L. Evaporation and enviroment. Symposium of the Society for Experimental Biology, v.19, p.205-234, 1965.

MOTA, F.S. Meteorologia Agrícola. 7. ed. São Paulo: Nobel, 1986. 376p.

NETTO, J. A.; AZEVEDO, P. V.; SOARES, J. M.. Coeficiente de cultura para quatro subperíodos de desenvolvimento da videira européia. In: CONGRESSO BRASileiro DE AGrOMETEOROLOGIA, 10., Piracicaba, 1997. Anais. Piracicaba: SBA, 1997. p. 620-622.

PENMAN, H.L. Natural evaporation from open water, bare soil and grass. Proceeding of the Royal Society of London, Serie A, v.193, p.120-146, 1948.

PEREIRA, A.B.; VILLA NOVA, N.A.; TUON, R.L. BARBIERI, V. Estimativa da evapotranspiração máxima da batata nas condições edafoclimáticas de Botucatu, SP, Brasil. Revista Brasileira de Agrometeorologia, v.3, n.1, p.53-58, 1995.

PEREIRA, A.R.; VILLA NOVA, N.A.; SEDIYAMA, G.C. Evapo(transpi)ração. Piracicaba: FEALQ, 1997. 183p.

PERES, J.G. Avaliação do modelo de Penman-Monteith, padrão FAO, para estimar a evapotranspiração de referência nas condições climáticas do Estado de São Paulo. Piracicaba, 1994. 116p. Tese (Doutorado) - Escola Superior de Agricultura "Luiz de Queiroz”, Universidade de São Paulo. 
PIZA JÚNIOR, C.T. A cultura do maracujá na região sudeste do Brasil. In: SIMPÓSIO SOBRE A CULTURA DO MARACUJÁ. Jaboticabal, 1998. Anais. Jaboticabal: UNESP, 1998. p. 20-45.

PIZZOL, S.J.S. de; WILDER, A.; ELEUTÉRIO, R.C. et al. Mercado Norte-americano de maracujá. Preços Agrícolas, p.41, fev., 2000.

RIZZI, L.C.; RABELLO,L.R.;MOROZINI FILHO, W.;SAVAKI, E.T.;KAVATI, E.T. Cultura do maracujá azedo. Campinas: CATI, 1998. 54 p. (Boletim Técnico, 235).

RUGGIERO, C.; SÃO JOSÉ, A.R.; VOLPE, C.A.; OLIVEIRA, J.C. de; DURIGAN, J.F.; BAUMGARTNER, J.G.; SILVA, J.R. da; NAKAMURA, K.; FERREIRA, M.E.; KAVATI, R.; PEREIRA, V. de P. Maracujá para exportação: aspectos técnicos da produção. Brasília: EMBRAPA-SPI, 1996, 64p. (Publicações Técnicas FRUPEX, 19).

RUGGIERO, C. Situação da cultura do maracujazeiro no Brasil. Informe Agropecuário, v.21, n. 206, p. 5-9, 2000.

SAAD, J. C. C.; SCALOPPI, E. J. Análise dos principais métodos climatológicos para estimativa da evapotranspiração. In: CONGRESSO NACIONAL DE IRRIGAÇÃO E DRENAGEM, 8., Florianópolis, 1988. Anais. Florianópolis: ABID, 1988. v. 2, p. 999-1021.

SANTOS, A.O.; BERGAMASCHI, O.; CUNHA, G.R. Necessidades hídricas da alfafa: Coeficientes de culrura $(\mathrm{Kc})$ no período pós-corte. Revista Brasileira de Agrometeorologia, v.4, n.1, p.37-40, 1996.

SEDIYAMA, G.C. Estimativa da evapotranspiração: Histórico, evolução e análise critica. Revista Brasileira de Agrometeorologia, v.4, n.1, p.1-12, 1996. 
SEDIYAMA, G.C. Necessidade de água para os cultivos. Brasília: ABEAS, 1987. $143 p$.

SENTELHAS, P.C. Estimativa diária da evapotranspiração de referência com dados de estação meteorológica convencional e automática. Piracicaba, 1998. 97p. Tese (Doutorado) - Escola Superior de Agricultura "Luiz de Queiroz", Universidade de São Paulo.

SILVA, F.C. Uso de dispositivos lisimétricos para medida da evapotranspiração de referência. Piracicaba, 1996. 68p. Dissertação (Mestrado) - Escola Superior de Agricultura "Luiz de Queiroz", Universidade de São Paulo.

SILVA, A.A.G. Maracujá-amarelo (Passiflora edulis f. Sims flavicarpa Deg.): aspectos relativos à fenologia, à demanda hídrica e à conservação pós colheita. Botucatu, 2001. 97p. Tese (Doutorado) - Faculdade de Ciências Agronômicas, Universidade Estadual Paulista "Júlio Mesquita Filho".

SMITH, M. Report on the expert consultation on revision of FAO methodologies for crop water requirements. Rome: FAO. 1991. 45p.

SOARES, W.R. Coeficientes de cultura no estado de desenvolvimento inicial para diferentes texturas de solos e condições de molhamento. Viçosa, 1999. 67p. Dissertação (M.S.) - Universidade Federal de Viçosa.

SOUSA, V.F. de. Níveis de irrigação e doses de potássio aplicados via fertirrigação por gotejamento no maracujazeiro amarelo (Passiflora edulis Sims. f. flavicarpa Deg.). Piracicaba, 2000. 178p. Tese (Doutorado) - Escola Superior de Agricultura "Luiz de Queiroz", Universidade de São Paulo.

SOUZA, J. S. I.; MELETTI, L. M.M. Maracujá: espécies, variedades, cultivo. Piracicaba: FEALQ, 1997. 179p. 
STAVELY, G.W.; WOLSTENHOLME, B.N. Effects of water stress on growth and flowering of Passiflora edulis (Sims) grafted to P.Caerulea L. Acta Horticulturae, n.275, p.251-258, 1990.

TEIXEIRA, A.H. de C.; AZEVEDO, P.V. de; SILVA, B.B.; SOARES, J.M. Consumo hídrico e coeficiente de cultura da videira na região de Petrolina, PE. Revista Brasileira de Engenharia Agrícola e Ambiental, v.3, n.3, p.413-416, 1999.

THORNTHWAIT, G.W. An approach toward a rational classification of climate. Geographysical Review, v.38, n.1, p.55-94, 1948.

UTSUNOMIYA, N. Effect of temperature on shoot growth, flowering and fruit growth of purple passion fruit (Passiflora edulis Sims var. edulis). Scientia Horticulturae, v.52, n.1/2, p.63-68, 1992.

VAN GENUCTHTEN, M. TH. A closed - from equation for predicting the hidraulic conductvity of unsaturated soils. Soil Science Society American Journal, v. 44, p. 892-898, 1980.

VAREJÃO, M.A.S. Meteorologia e climatologia. Brasília: Instituto Nacional de Meteorologia (INMET), 2000. 509p.

VASCONCELLOS, M.A.S.; DUARTE FILHO, J. Ecofisiologia do maracujazeiro. Informe Agropecuário, v. 21, n. 206, p. 25-28, 2000.

VERAS, M.C. Fenologia, produção e caracterização físico-química dos maracujazeiros ácido (Passiflora edulis f. flavicarpa Deg) e doce (Passiflora alata Dryand) nas condições de Cerrado de Brasília-DF. Lavras, 1997. 105p. Dissertação (Mestrado) Universidade Federal de Lavras. 
VILLA NOVA, N.A.; PEDRO JUNIOR., M.J.;PEREIRA, A.R.; OMETTO, J.C. Estimativa de graus dia acumulados acima de qualquer temperatura base, em função de temperaturas máxima e mínima. Cadernos de Ciências da Terra, n. 30, p. 1-7, 1972.

VILLA NOVA, N.A. Principais métodos climáticos de estimativa de aplicação de água de irrigação. Piracicaba: ESALQ, Departamento de Física e Meteorologia, 1983. 22p.

WATSON, D.P.; BOWERS, F.A. Long days produce flowers on passionfruit. Hawaii Farm Science, v.14, n.2 p.3-5, 1965.

WRIGHT, J.L.; JENSEN, M.E. Peark water requirements in southern Idaho. Journal of the Irrigation and Drainage Division, v.98 (IR 2), p.193-201, 1972. 